\title{
WestVirginiaUniversity
}

THE RESEARCH REPOSITORY @ WVU

Graduate Theses, Dissertations, and Problem Reports

2020

\section{Upstream Tailings Dam - Liquefaction}

\author{
Mladen Dragic \\ md0125@mix.wvu.edu
}

Follow this and additional works at: https://researchrepository.wvu.edu/etd

Part of the Mining Engineering Commons

\section{Recommended Citation \\ Dragic, Mladen, "Upstream Tailings Dam - Liquefaction" (2020). Graduate Theses, Dissertations, and Problem Reports. 7761.}

https://researchrepository.wvu.edu/etd/7761

This Problem/Project Report is protected by copyright and/or related rights. It has been brought to you by the The Research Repository @WVU with permission from the rights-holder(s). You are free to use this Problem/Project Report in any way that is permitted by the copyright and related rights legislation that applies to your use. For other uses you must obtain permission from the rights-holder(s) directly, unless additional rights are indicated by a Creative Commons license in the record and/ or on the work itself. This Problem/Project Report has been accepted for inclusion in WVU Graduate Theses, Dissertations, and Problem Reports collection by an authorized administrator of The Research Repository @ WVU. For more information, please contact researchrepository@mail.wvu.edu. 
Graduate Theses, Dissertations, and Problem Reports

2020

Upstream Tailings Dam - Liquefaction

Mladen Dragic

Follow this and additional works at: https://researchrepository.wvu.edu/etd

Part of the Mining Engineering Commons 


\section{Upstream Tailings Dam - Liquefaction}

\section{Mladen Dragic}

Problem report submitted to the Benjamin M. Statler College of Engineering and Mineral Resources

At West Virginia University in partial fulfillment of the requirements

for the degree of

Master of Science

In

Mining Engineering

Brijes Mishra, Ph.D., Chair

Yi Luo, Ph.D.

Jeremy Gouzd, Ph.D.

Department of Mining Engineering

Morgantown, West Virginia 2020

Keywords: Tailings Dam; Safety Factor; Upstream Construction Method; Embankment; Impoundment; Dike; Shear Strength 


\begin{abstract}
Upstream Tailings Dam - Liquefaction
\end{abstract}

\title{
Mladen Dragic
}

The collapse of Dam I, tailings dam, at Vale S.A.'s ("Vale") of the Córrego do Feijão Iron Ore Mine in Brazil was an accident that caused over 270 casualties and made irreparable damage to the surrounding environment. The exact reason for the failure is not known however, liquefaction was suspected to be the most influencing factor in the failure.

Liquefaction failure of impoundment is increasing concern in the mining community and especially mine planners who will have to design and build the tailings dam. Different design methods are available with varied degree of challenges. Upstream construction methods, as one of the tailings dam types, is more susceptible to liquefaction. To investigate the effect of tailings on the impoundments, the research effort in this report determined four scenarios that affected the impoundment. Slide2, a two dimensional limit equilibrium based program was used to analyze four parametric conditions for predicting the failure of the impoundment. Each scenario represents a unique case where number of external and internal factors simulated the field condition.

In addition to the safety factor, regression analysis was conducted to predict the future Factor of Safety by varying parameters such as cohesion, relative density, and friction angle. Analysis of the given scenarios showed significant sections of the dam stressed due to the weight of the tailings with high internal water level. 


\section{Table of Contents}

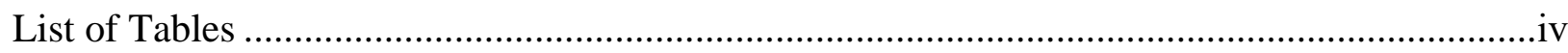

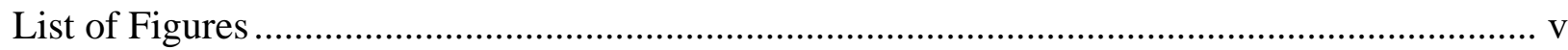

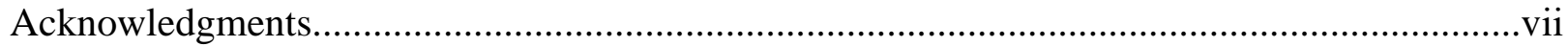

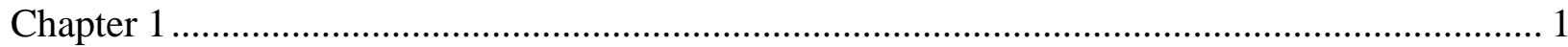

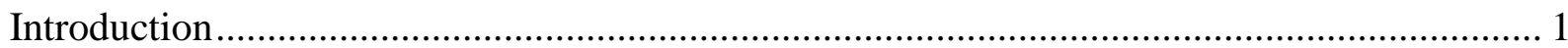

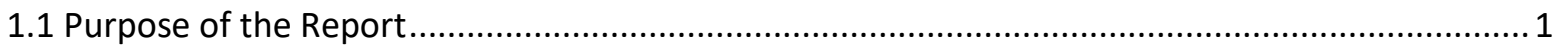

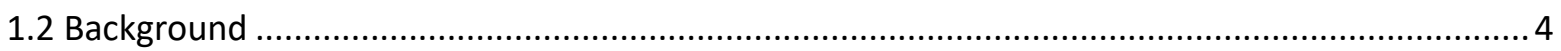

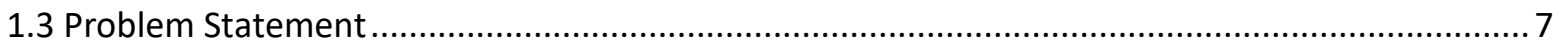

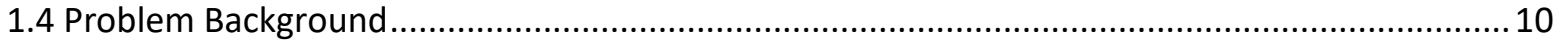

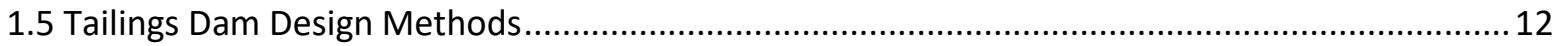

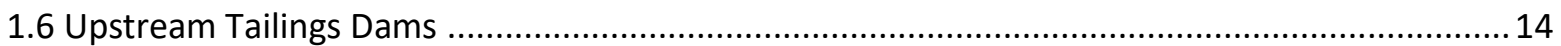

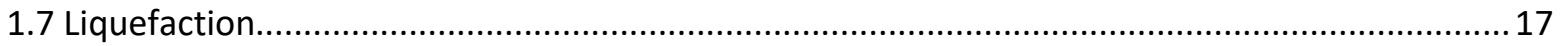

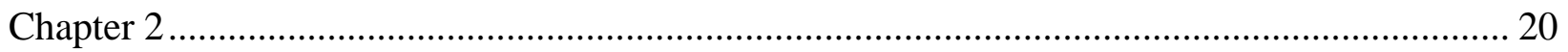

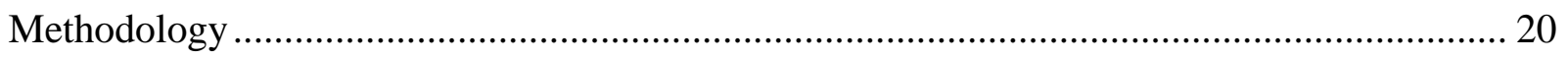

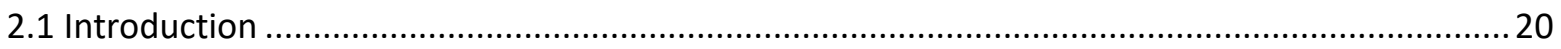

2.2 Development

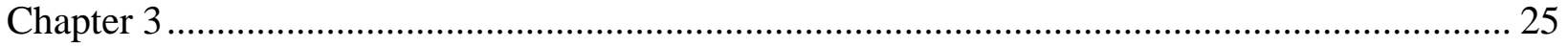

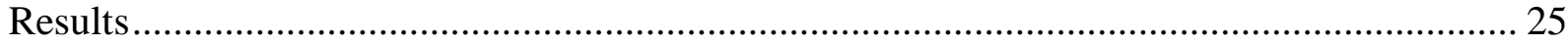

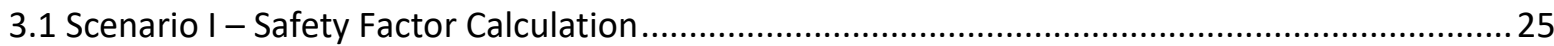

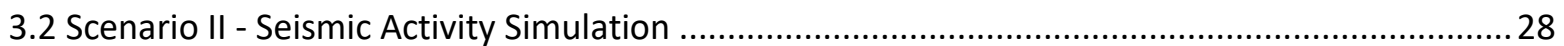

3.3 Scenario III - Critical Acceleration Simulation ............................................................................ 31

3.4 Scenario IV - Perfect Drainage (No water pressure) ............................................................. 34

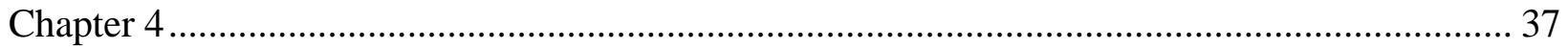

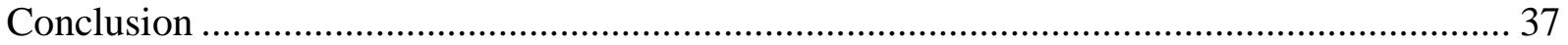

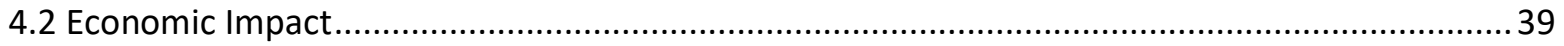

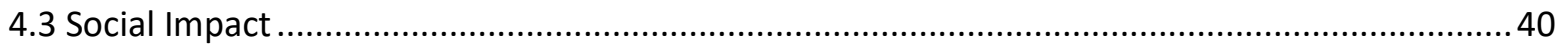

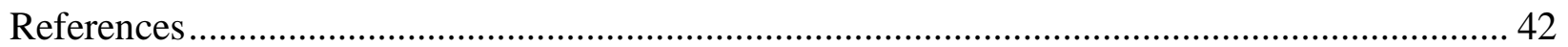




\section{List of Tables}

Table 1 - Embankment raising progress (Robertson et al., 2019)...........................6

Table 2 - Geotechnical parameters of the Dam I (Pirete and Gomes, 2013)...................21

Table 3 - Regression analysis coefficients of significant predictors for the first scenario..........27

Table 4 - Regression analysis coefficients of significant predictors for the second scenario.........30

Table 5 - Horizontal seismic coefficient (Melo and Sharma, 2004)............................

Table 6 - Regression analysis coefficients of significant predictors for the third scenario..........33

Table 7 - Regression analysis coefficients of significant predictors for the fourth scenario........36 


\section{List of Figures}

Figure 1 - The Dam I before the collapse (Guardian News, 2019) .........................2

Figure 2 - The Dam I when collapse started (Guardian News, 2019) ........................

Figure 3 - Couple seconds after the collapse started (Guardian News, 2019....................

Figure 4 - Direction of the mudflow few seconds after the collapse of the dam (Guardian News,

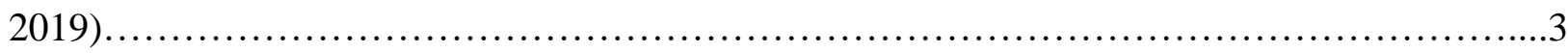

Figure 5 - The wave of the mud flowing downhill (Guardian News, 2019)...................4

Figure 6 - Tailing's mudflow down the hill (Darlington et al., 2019).........................11

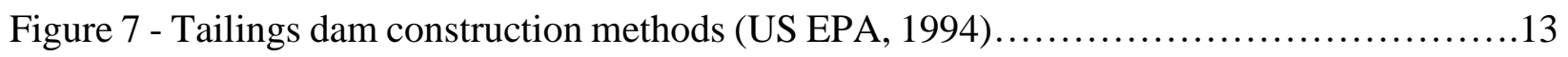

Figure 8 - World's distribution and ratio of tailings dams by construction method (Lyu et al.,

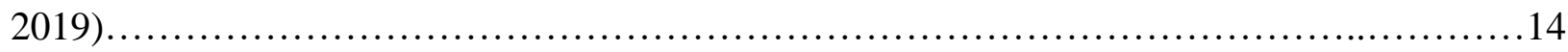

Figure 9 - Upstream method of construction (McLeod and Bjelkevik 2017)..................15

Figure 10 - The relation between normal and shear stress during slide (Chaulya and Prasad,

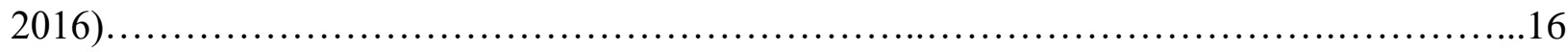

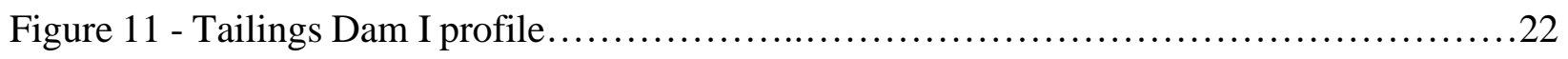

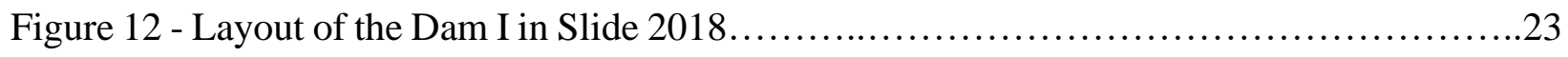

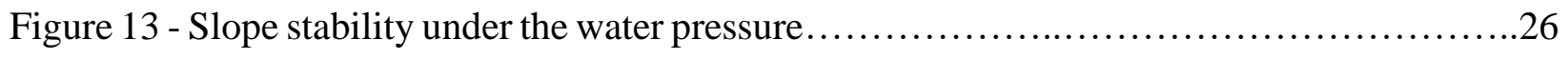

Figure 14 - Critical part under the seismic activity ..................................29 
Figure 15 - Critical acceleration simulation.

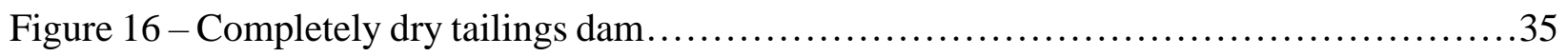

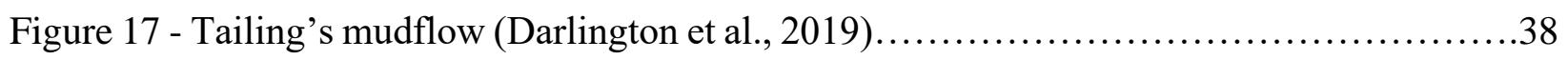

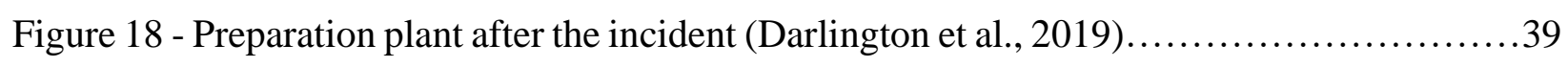

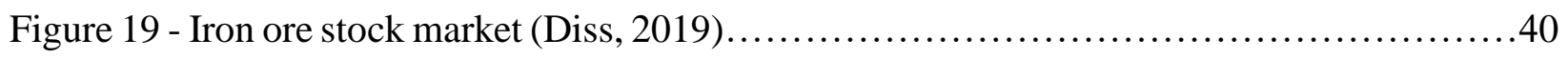




\section{Acknowledgments}

Without any doubt, I can say that Dr. Brijes Mishra played a key role in my graduation process. My pleasure was to work and cooperate with such a researcher, advisor, and most importantly a friend. He was very encouraging, motivating, and helpful during this process of producing this report without which suggestions and guidance I would never be able to finish. I am thankful for the time and patience he has for me.

I also need to mention Dr. Yi Luo who was always there for me, who was the first professor on the department who became my true friend. Thank you, Dr. Luo.

And the last but not the least, Dr. Jeremy Gouzd who found time to review my report and accepted to be part of my educational journey, the professor who taught me a lot about safety, economics, and how important critical thinking is.

Also, huge thanks go to my family who was going through this with me every day, and without their support I would never be able to make this. 


\section{Upstream Tailings Dam - Liquefaction}

\section{Chapter 1}

\section{Introduction}

\subsection{Purpose of the Report}

On January $25^{\text {th }}, 2019$, Dam I at Vale S.A.'s ("Vale") of the Córrego do Feijão Iron Ore Mine in Brazil collapsed and released about 10 million cubic meters of mining wastes that caused over 270 casualties and massive environmental disaster.

From an engineering standpoint, there are some unique facts about this failure. First of all, the dam showed no indications prior to the collapse. There were several methods enforced to measure and detect deformations on the embankment, but none of the preventive measures detected any changes within the dam. Secondly, video footage was made and this was a rare situation where the embankment failure was recorded.

As a result of catastrophes in the past few years (the Brumadinho Dam disaster, the Mariana Dam disaster), tailings dams became a subject of interest to many governments. Currently, every country is reviewing and evaluating its policies to prevent disasters and to secure active and retired tailings dams.

This report is focused on developing four different scenarios representing four different conditions of a tailings dam, according to internal and external factors such as groundwater, water table, external pressures, and so on. Every scenario will be discussed and presented later in the report. 
In the figures below (Figures 1, 2, 3, 4, and 5) the video footage is presented and the look of the dam before and during the collapse.

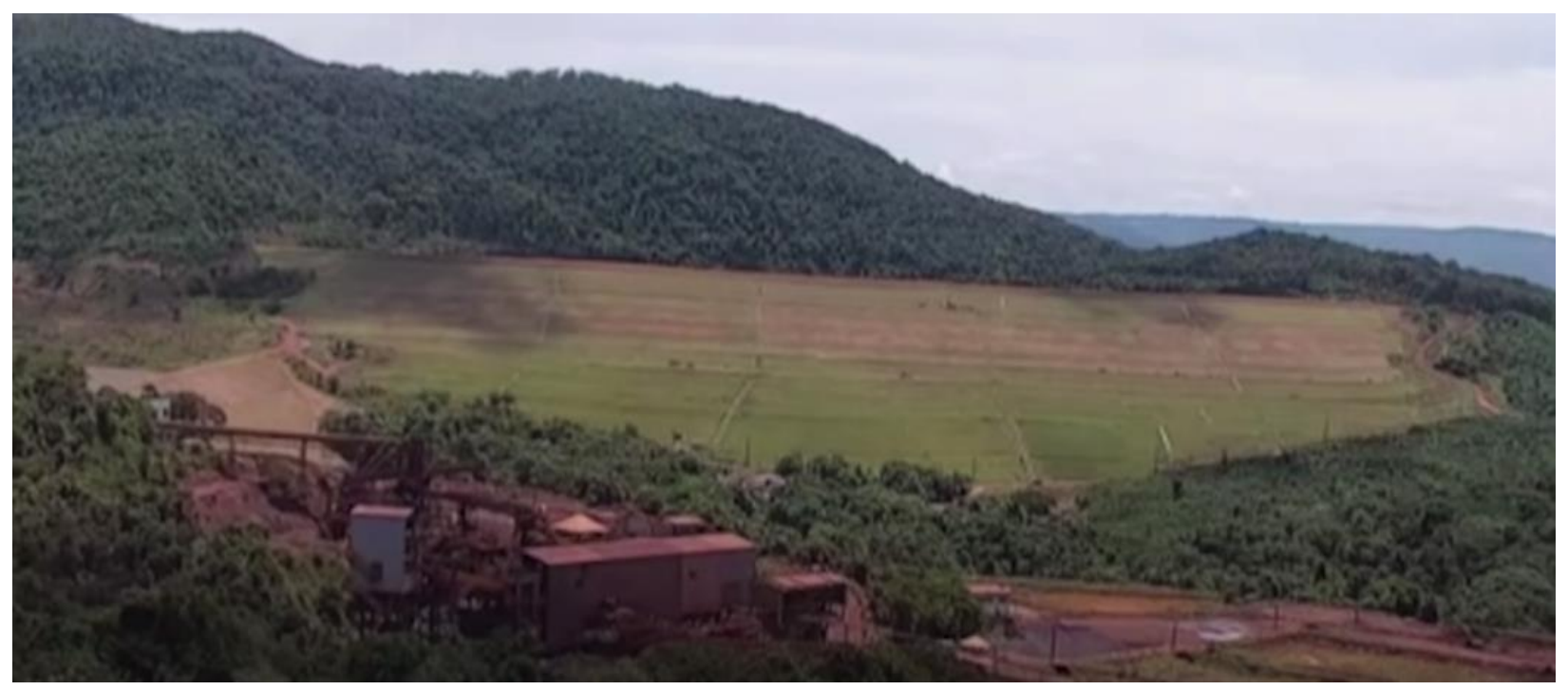

Figure 1 - Dam I before the collapse (Guardian News, 2019)

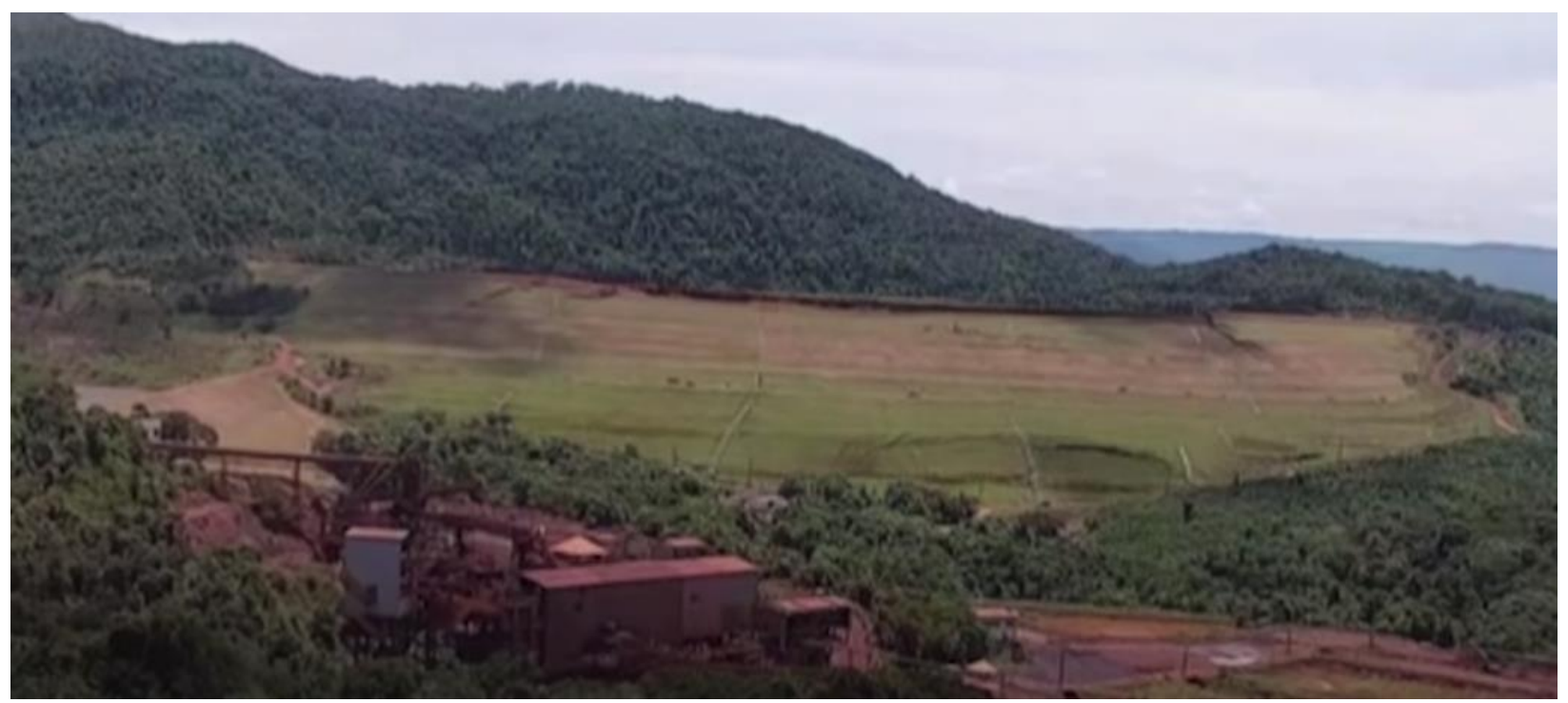

Figure 2 - Dam I when collapse started (Guardian News, 2019) 


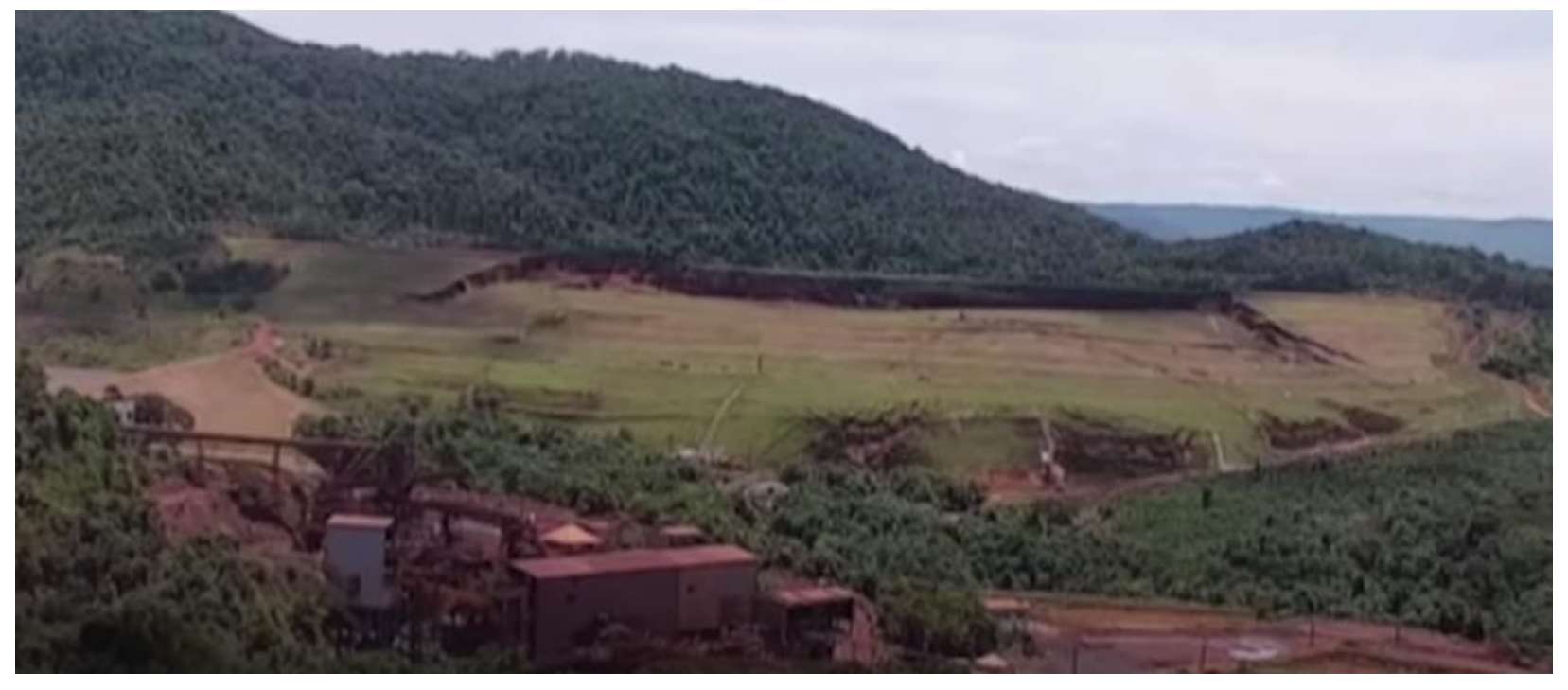

Figure 3 - A few seconds after the collapse started (Guardian News, 2019)

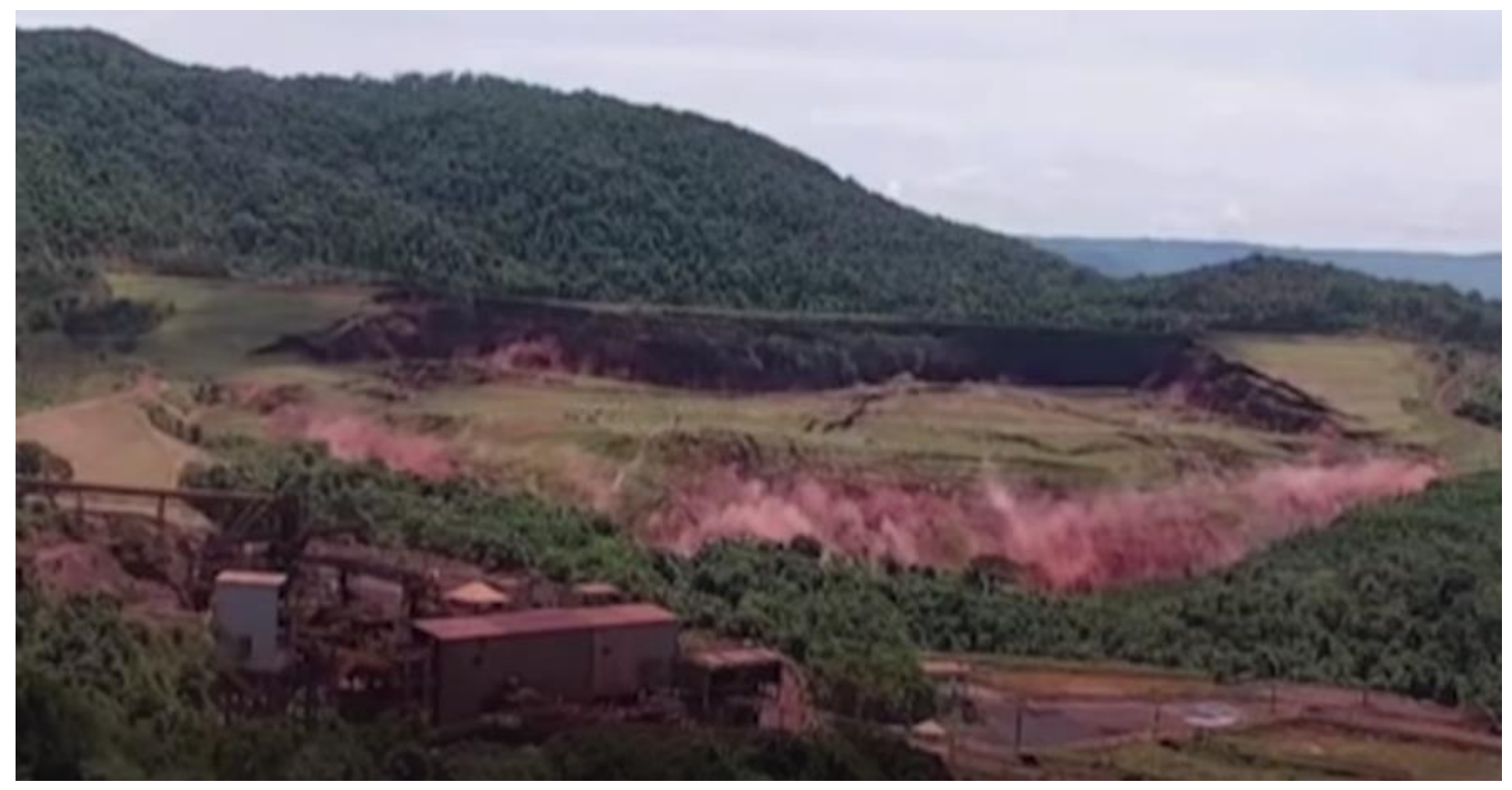

Figure 4-The direction of the mudflow a few seconds after the collapse of the dam (Guardian

News, 2019) 


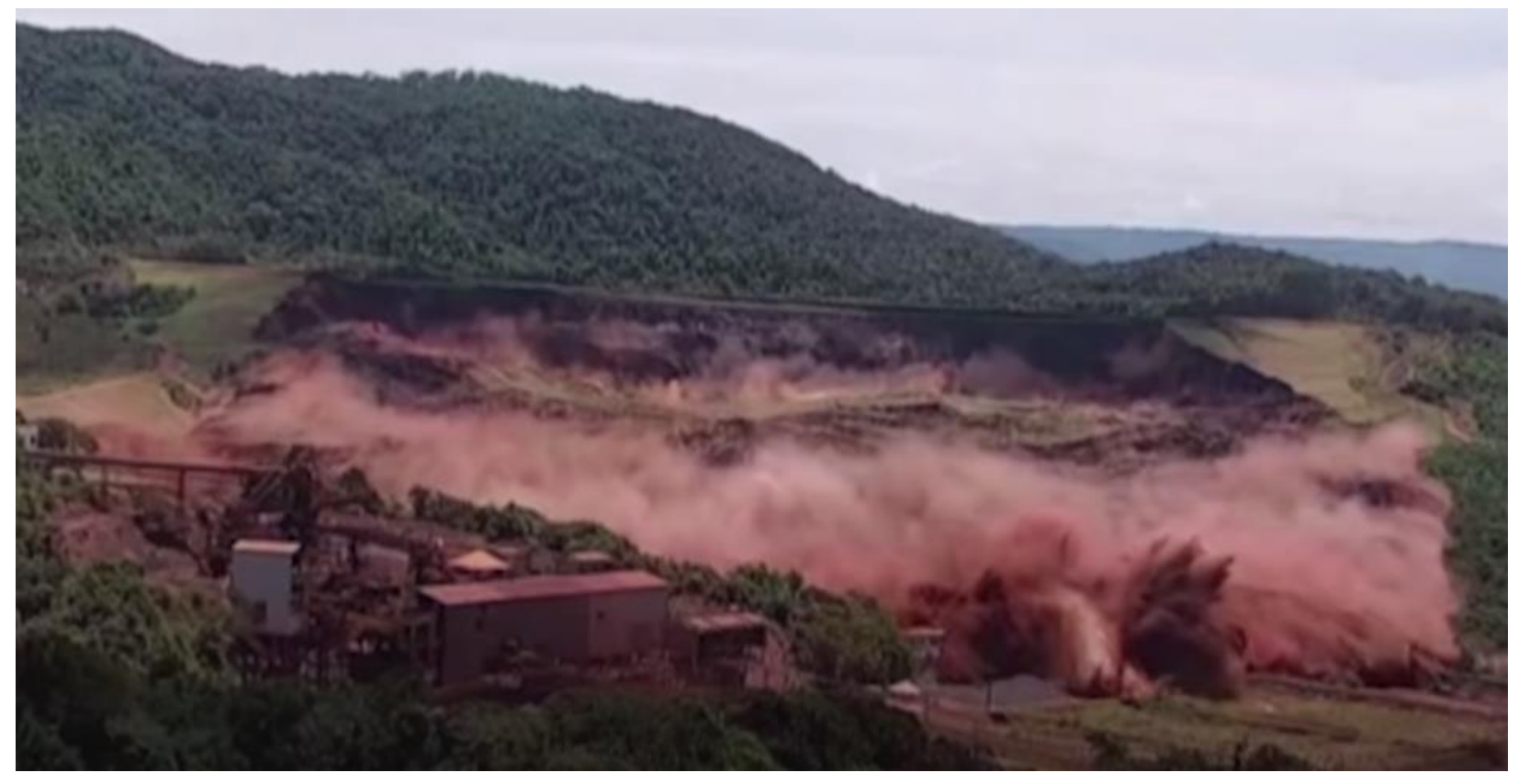

Figure 5 - The wave of the mud flowing downhill (Guardian News, 2019)

\subsection{Background}

Dam I looked like any other ordinary tailings dam. According to measuring devices (survey monuments, inclinometers, ground-based radar, and others), there were no signs of deficiencies. Only a few days before the collapse occurred, a drone was flown over the dam recording a highquality video and recorded no sign of concern.

Although the collapse was not seen as a possible outcome when no distress is presented, indeed it happened. The history of the dam's construction indicates the possible reason for the failure (Robertson et al., 2013).

The dam was built in 10 stages and took about 37 years, using the upstream construction method, which will be discussed later. Moreover, that was one of the reasons why the material liquefied. According to Robertson et al. (2019), the failure was the result of the static liquefaction 
within the materials of the dam. Liquefaction within the materials of the tailings dam is wellknown to mining engineers, but it's still very hard to explain, as well as to control; therefore, liquefaction will be discussed later.

For disposing of significant amounts of waste produced at a mine processing plant, various sites are engineered to store the mine wastes that vary in size and design. As the mines are deep and a large amount of overburden is handled with waste rock dilution, large tailings disposal facilities are required.

The increasing demand for lower-grade deposits makes it more challenging now to dispose of a vast amount of material than ever before. Modern tailing embankments can reach more than several hundred feet in height and these impoundments can cover several square miles (US EPA, 1994). Dams are constructed to be cheap, convenient, environmentally friendly, and they have to satisfy: a) long-term stability, b) prevention of environmental contamination of waters, and c) returning area for future use.

Nevertheless, inactive tailing impoundments are also part of the concern due to their shape after long-term windblown dispersal, acid drainage, water contamination, etc. Costs of restitution can sometimes be even more than the costs of original design and operation.

Designing the tailings impoundments depends on many factors and they are case-specific. Also, designing the impoundment varies in methods, location, and capacity, and it all depends on the climate as well as the topographic, geologic, geotechnical, and hydrogeologic characteristics of the location, in addition to regulatory requirements related to dam safety and environmental performance (US EPA, 1994). 
Therefore, the initial and final size and design of tailings dams change over time. This happens mainly because the initial size and design are based on current regulations and estimated reserves. So, while regulations change over time and more reserves are getting proven, new (final) size and design need to be created.

In the table below (Table 1) the raising stages of the tailings dam are presented.

Table 1 - Embankment raising progress (Robertson et al., 2019)

\begin{tabular}{|c|c|c|c|c|c|c|}
\hline Stage & Year & $\begin{array}{l}\text { Raising } \\
\text { ID }\end{array}$ & $\begin{array}{c}\text { Top } \\
\text { Elevation } \\
(\mathrm{m} \mathrm{msl})\end{array}$ & $\begin{array}{l}\text { Height } \\
\max \\
(\mathrm{m})\end{array}$ & $\begin{array}{l}\text { Project Design } \\
\text { Firm }\end{array}$ & $\begin{array}{c}\text { Construction } \\
\text { Company }\end{array}$ \\
\hline 1 & 1976 & $\begin{array}{l}\text { Starter } \\
\text { Dam } \\
\text { (first) }\end{array}$ & 874 & 18 & Christoph Erb & Emtel \\
\hline 2 & 1982 & \multirow{5}{*}{ Second } & 877 & 21 & \multirow{5}{*}{ Tecnosan } & Tercam \\
\hline 3 & 1983 & & 879 & 23 & & Unknown \\
\hline 4 & 1984 & & 884 & 28 & & $\begin{array}{l}\text { Construtora Sul, } \\
\text { Minas }\end{array}$ \\
\hline 5 & 1986 & & 889 & 33 & & Unknown \\
\hline 6 & 1990 & & 891.5 & 35.5 & & $\begin{array}{l}\text { Unienge Com. e } \\
\text { Constr. Ltda. }\end{array}$ \\
\hline 7 & 1991 & \multirow[t]{2}{*}{ Third } & 895 & 39 & \multirow{2}{*}{$\begin{array}{l}\text { Chammas } \\
\text { Engenharia }\end{array}$} & $\begin{array}{l}\text { Construtora Sul, } \\
\text { Minas }\end{array}$ \\
\hline 8 & 1993 & & 899 & 43 & & Unknown \\
\hline 9 & 1995 & Fourth & 905 & 49 & \multirow{5}{*}{ Tecnosolo } & CMS Constr. S.A. \\
\hline 10 & 1998 & Fifth & 910 & 54 & & $\mathrm{U} \& \mathrm{M}$ \\
\hline 11 & 2000 & Sixth & 916.5 & 60.5 & & $\begin{array}{c}\text { Constr. Dragagem } \\
\text { Paraopeba }\end{array}$ \\
\hline 12 & 2003 & Seventh & 922.5 & 66.5 & & $\begin{array}{c}\text { Construtora Impar } \\
\text { Ltda. }\end{array}$ \\
\hline 13 & 2004 & Eighth & 929.5 & 73.5 & & Integral \\
\hline 14 & 2008 & Ninth & 937.0 & 81.0 & Geoconsultoria & Integral \\
\hline 15 & 2013 & Tenth & 942.0 & 86.0 & Geoconsultoria & Salum Enga \\
\hline
\end{tabular}


Tailings dam engineering is part of everyday improvements. A dynamic environment with constantly changing conditions requires daily inspections and corrections.

Three factors that need to be satisfied to have a well-engineered embankment and impoundment are:

- cost,

- stability, and

- environmental friendliness.

This report will focus on slurry tailings because they are the starting point for liquefaction.

Slurry impoundment can be built in four different forms such as valley impoundment, ring dikes, in-pit, and specially dug pits impoundment (Ritcey 1989). Our main focus is on valley impoundment because their form is critical when it comes to liquefaction potential.

For mitigation purposes, some tailings can be:

- dewatered (when their pulp density thickens to more than 60 percent); or

- dried (by lowering the moisture content up to 25 percent or less).

Further information about this will be given later.

\subsection{Problem Statement}

Tailings dams are a massive structure and they serve as a wall between mining leftovers and

free space. In the last several years, tailings impoundments tend to rapidly increase in height, partly because there is limited land space, and partly because of production increases by the mine. Because of these mentioned reasons, maintaining the stability of the dam is challenging. The most critical impoundments are upstream tailings dams because of their construction, which will be 
discussed later. Other structures like centerline and downstream methods should also be seriously considered, but not as much as the upstream construction method.

The most common cause of a tailings dam instability is nonuniform dams and high porepressure within tailings. Therefore, keeping the pore pressure low by installing and controlling the monitoring devices is mandatory to regulate the safety of the dams. Every dam has its upper limit, or the heightening rate, at which developing shear failure due to high pore pressure can be disregarded. According to Lottermouser (2010), major and minor environmental concerns with tailings dams are:

- the visual impact of the large engineered structure,

- stability of the dam and potential release of tailings,

- closure of the tailings dam,

- release of radiation from tailings,

- dust generation,

- seepage from the tailings into the surface and the groundwater.

The most threatening factors to tailings dam stability, addressed by Priscu (1999) are quality of construction materials, the in-situ density of the disposed of materials, location of free watersurface/saturation table, and characteristics of the downstream slope. Because of the difficulties in predicting and controlling material behavior, tailings dams built using sand need special attention. The in-situ density of the disposed of materials is in direct relationship with liquefaction. When the material is water-saturated and not compacted, susceptibility to liquefy is high. This behavior is closely related to the upstream method of construction because of the upper dike's weak foundation. According to Youd et al. (1994) when the water table lies within 10 meters of the 
ground surface, liquefaction has been most abundant. Moreover, only a few instances of liquefaction occurred in the areas where the groundwater was deeper than 20 meters.

Liquefaction is a state of the soil by which solid sediments temporarily lose strength and behave as a viscous liquid (Youd, 1994). Liquefaction does not occur at random but as a result of many internal and external factors.

A recent study from Pacheco (2019) shows that the various trigger factors causing liquefaction are: (1) overtopping, (2) internal erosion, (3) erosion of the dam toe, (4) a weak foundation, (5) drainage system failure and injection of water, (6) an increasing water table due to rainfall, and (7) an increase of the saturation due to input of groundwater, etc. Overtopping is a direct result of design error or waves due to strong winds. Sometimes, even erosion of a slope above a tailings dam may lead to overtopping the tailings basin with rocks. Some tests showed the possibility of liquefaction in materials with a saturation degree of $80 \%$ (Martin, 1999).

According to Pirete and Gomes (2013), liquefaction is a phenomenon of the strain-softening and cohesionless soil triggered by static or seismic loading. They state that the flow failure is the result of the greater static shear stress more so than the liquefied shear strength. Their research is focused on estimating the shear resistance of softened soil using the common SPT (standard penetration test) and CPT (cone penetration test) results. 


\subsection{Problem Background}

As previously mentioned, Dam I unexpectedly collapsed on January 25, 2019, releasing approximately 9.7 million cubic meters of mining waste, which is about $75 \%$ of the total prefailure volume of approximately 12.7 million cubic meters with a maximum tailings thickness of about 76 meters prior to the failure (Robertson et al., 2019). The mud reached the speed of 20 meters per second and flowed approximately 5 miles downhill until reaching the Paraopeba River (Figure 6), thereby destroying everything in its way such as homes, offices, bridge, the mine's railway branch, etc. (WISE, 2020). The catastrophe was sudden without any major pre-failure warning sign that could have possibly alerted management's attention to prevent the incident.

According to Robertson et al., (2019) the height of the dam was approximately 80 meters with a crest of approximately 700 meters. The evidence from the video footage and the unexpected mudslide flow distance shows that the failure was the result of flow liquefaction within the materials of the tailings dam. 


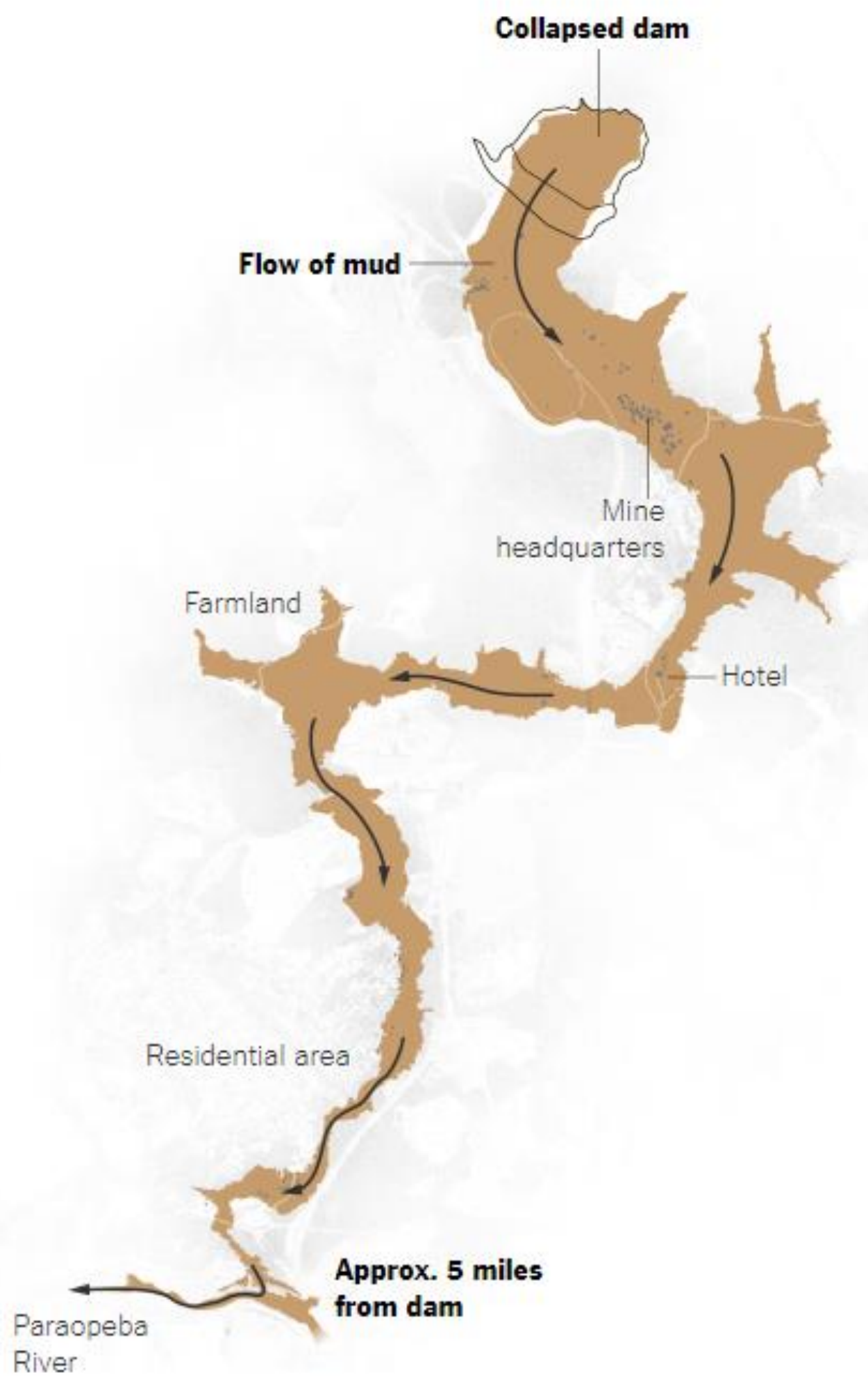

Figure 6 - Tailing's mudflow down the hill (Darlington et al., 2019) 


\subsection{Tailings Dam Design Methods}

Two types of impoundments, the raised embankment, and the retention dam are commonly practiced in the mining industry. A combination of these two construction methods is also practiced; however, it is rarely used. Retention dams are often used on rivers as part of the hydropower plant, while raised embankments are most common in the mining industry.

It is important to emphasize that the construction of the tailings dams is designed in advance of the mining operations, mainly because the entire construction has to be adjusted to the specific site conditions, tailings characteristics, mine and mill management, etc. (Priscu, 1999).

The main difference between water retention dams and raised embankments is that the construction of raised embankments is completed in stages. The first (initial) dike is constructed a couple of years after the commencement of the mill operation.

Raised embankments are built by three different methods (Figure 7):
a) upstream,
b) centerline, or
c) downstream method. 


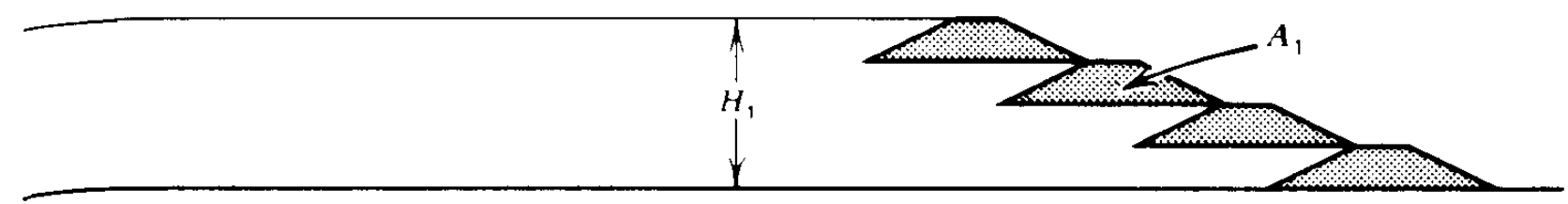

(a)

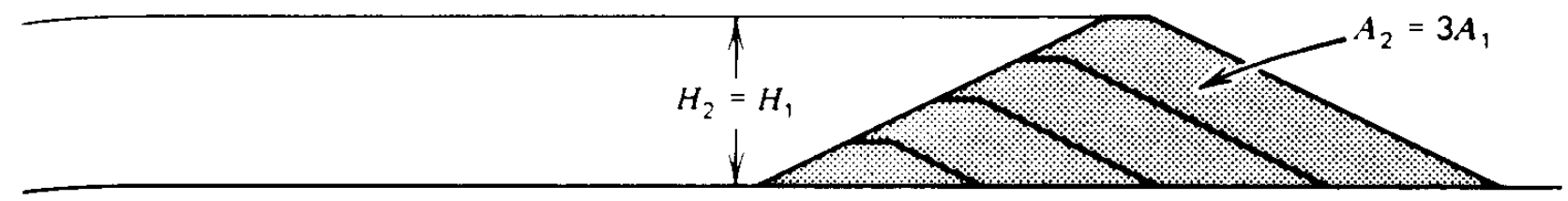

(b)

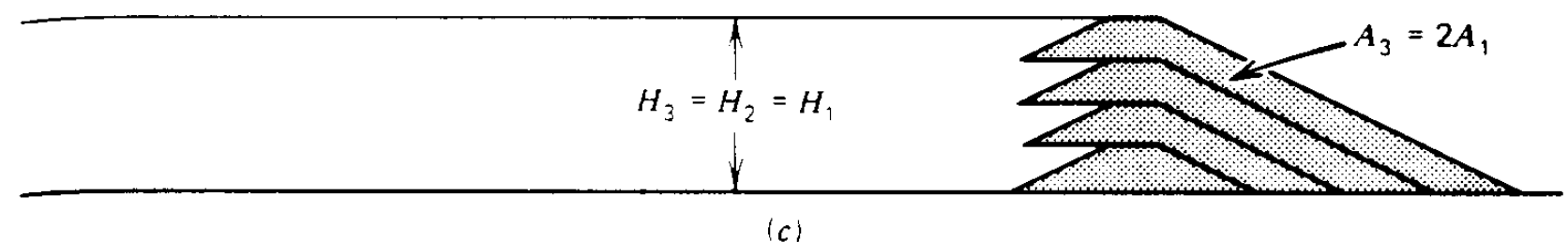

Figure 7 - Tailings dam construction methods (US EPA, 1994)

There are about 3,500 active tailings dams around the world.

The figure below (Figure 8) represents the ratio and distribution of the different types of methods of raised embankments in the world. 


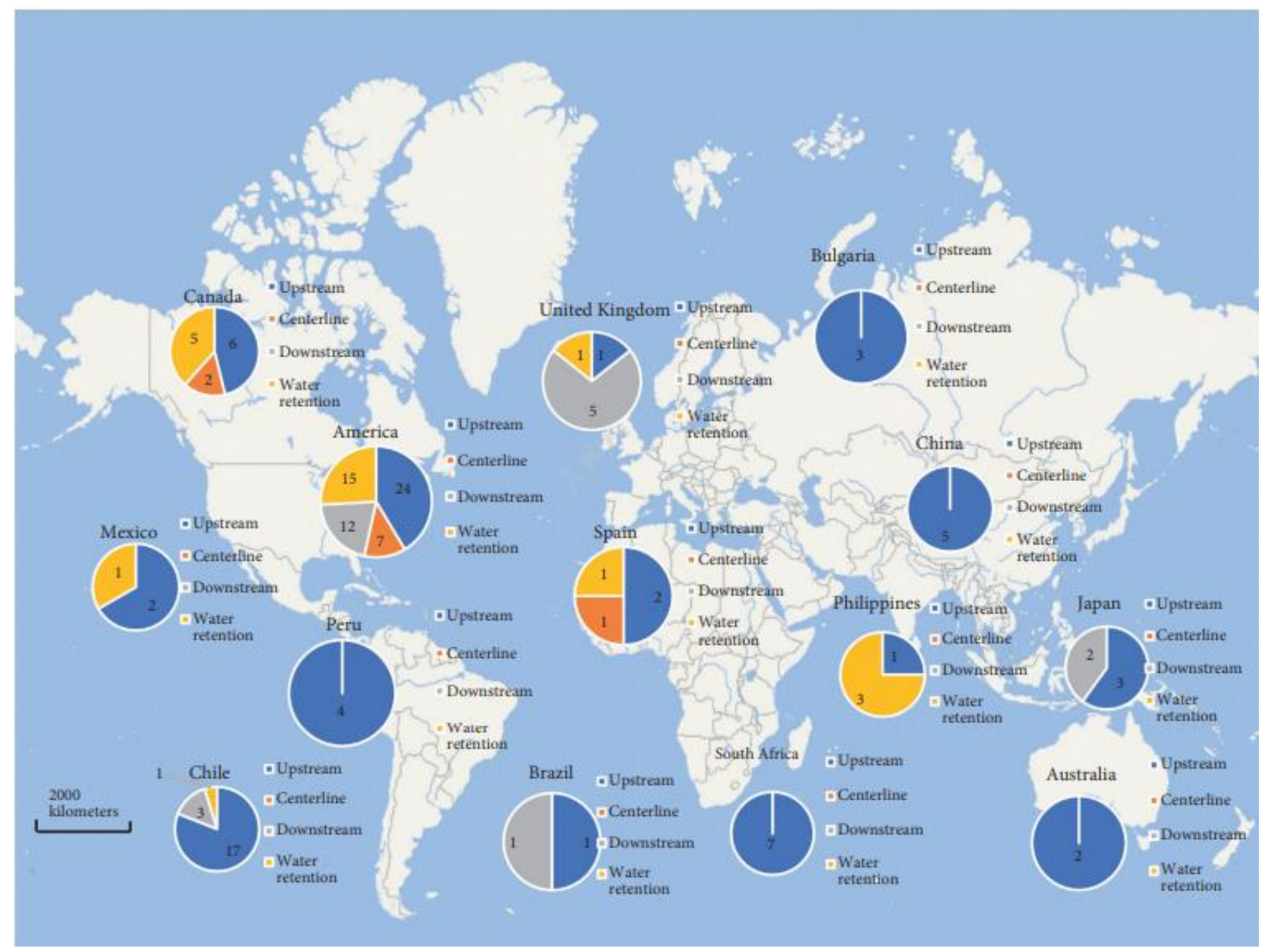

Figure 8 - Worldwide distribution and ratio of tailings dams by methods of construction (Lyu et

$$
\text { al., 2019) }
$$

\subsection{Upstream Tailings Dams}

As the oldest and the most inexpensive method of construction, upstream tailings dams are widespread across the globe. The design and construction of the embankments of this type of tailings dam start with building a downstream toe first. While discharging material from the top of the starter dam using cyclones or spigots, a wide beach is formed from the raw material, and immediately it is the foundation for the next dike as shown in Figure 9. Sometimes, new dikes can be built from another type of material, which is preferable. Therefore, before building the next dike, mechanical compaction is required to consolidate the foundation for the next stage. 
According to Vick (1990), when the upstream method of construction is being used, the tailings should have no less than 40 to 60 percent of sand. The cut off for using the downstream method versus the upstream method of construction, according to Brawner (1973), should be the size of the particles. If the particle sizes are too fine and a tractor cannot operate within the first 30 to 60 meters of beach, the upstream method of construction should be avoided (US EPA, 1994).

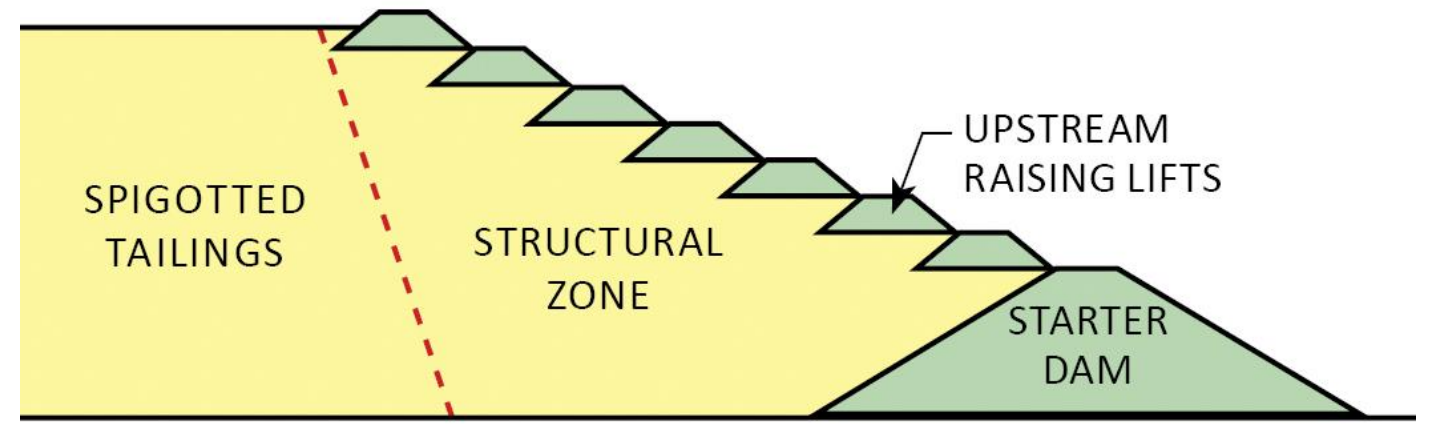

Figure 9 - Upstream method of construction (McLeod and Bjelkevik 2017)

Some other factors that should be considered in decision-making are:

- the capacity of water storage.

- $\quad$ seismic liquefaction susceptibility.

- phreatic surface control.

- the rate of dam raising.

The main characteristic of an embankment built using an upstream method of construction is a low relative density with high water saturation (Tailings). Because of that and some other factors, such as different magnitude and duration of vibration that are caused by heavy machinery, trains, blasting, seismic activity, etc., liquefaction may occur. 
Shear strength plays an important role in slope stability. To evaluate the stability of the dam slope, it is crucial to use the failed relationship, which is shown in Figure 10. For liquefied soil, shear strength may be reduced to near zero, which means that the material can easily penetrate the dam, and the material can collapse and flow.

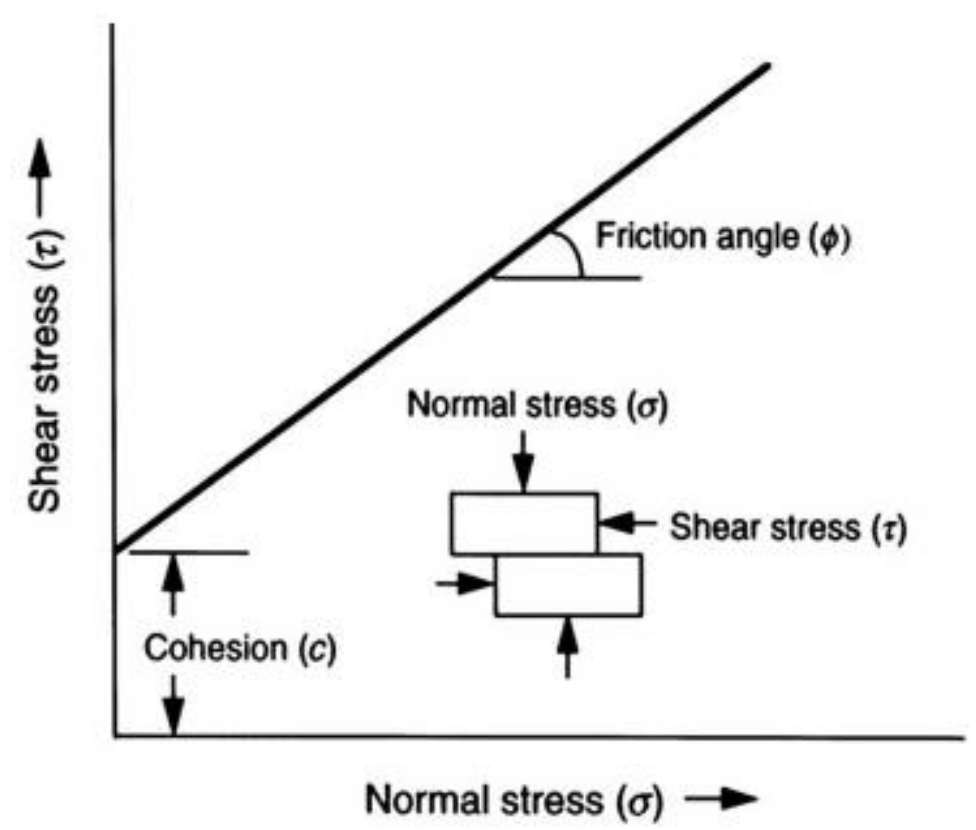

Figure 10 - The relationship between normal and shear stress during a slide (Chaulya and

Prasad, 2016)

The pore pressure within the material limits the height of the embankment and the number of dikes. Low pore pressure can lead to shear failure, releasing the tailings downstream.

As a mitigation factor, drainage zones should be installed at the very beginning of the dam construction, which will maintain low pore pressure. Although, it is hard to prevent the blockage of drains because the material will usually gather around the drainage system, which may prevent contaminated water from flowing out. Therefore, it is very important to maintain the system. 
Advantages of this construction method are:

- simple and inexpensive construction.

- a small amount of material needed to build the starter dam.

- requires less material for building other dikes.

Disadvantages are:

- not recommended for a region with high rainfall, mostly because the structure cannot hold a large amount of water. The pond should always be kept as far from the crest as possible.

- an upstream tailings dam is very sensitive to seismic movements.

- $\quad$ once a dam is built, it is not suitable for large corrections if some conditions change.

\subsection{Liquefaction}

Liquefaction represents instability within the soil. When water-saturated soil loses stability and strength by ground shaking, tailings may behave like liquefied soil and they can pass through narrow openings and can stream for a long distance.

According to Terzaghi's Principle of Effective Stress, liquefaction will occur when the pore pressure is equal to a total normal stress:

$\sigma=\sigma^{\prime}+u$

$\sigma^{\prime}=\sigma-u$

Where: $\quad \sigma-$ total stress,

$\sigma^{\prime}$ - effective stress,

$u$ - pore pressure. 
According to US EPA (1994), factors affecting liquefaction are:

1) Soil type - if the grain size form suspension, the tailing material is uniform in size (fine material).

2) Relative density or compactness - when a material is not compressed (it is water-saturated), it may lead to liquefaction.

3) Magnitude and duration of the ground shaking - caused by blasting, operating of heavy equipment, seismic activities, etc.

4) Location of the water table - it is preferable to keep the water table close to the foundation; etc.

The calculation for each dam is necessary to obtain a safety factor and to ensure that all parameters are incorporated. Having a relative density of $60 \%$ of fine sands for the tailings embankment, maintaining a low level of the water table - close to the foundation, and satisfying other factors may significantly reduce and prevent tailings from liquefaction. A factor of safety greater than 1.0 implies that shear strength within a material is greater than a driving force that can initiate failure. Nowadays, regulations often require a factor of safety to be at least 1.5.

\section{Scope of Work}

With a high potential for liquefaction, tailings dams' stability deserves a serious approach in evaluating and calculating factors of safety; while considering factors, such as density, cohesion, and friction angle for each type of material used in the dam construction. The overall objective is to figure out what external and internal factors may affect the safety factor while keeping Geotechnical parameters constant.

The specific aims of this study are as follows: 
i. Collect the data for each type of material used; both for the tailings and the dam's construction (density, cohesion, friction angle, height).

ii. Plug the data into the software, add the water table, and the external pressure of the crest of the tailings, to the object.

iii. Consider multiple scenarios for different external impacts, such as rainfall, ground shaking, drought, etc.

iv. Calculate the safety factors for each scenario.

v. Apply condition changes within the material and testing the stability of the dam.

vi. Interpret the results. 


\section{Chapter 2}

\section{Methodology}

\subsection{Introduction}

The purpose of this report is to develop four models with the same parameters, where each model will be tested for stability from different perspectives, which will be discussed later. To do so, the student version software of Slide 2018 from Rocscience Inc. and AutoCAD 2019 from Autodesk was used to develop the models. Slide 2018 is a two-dimensional slope stability program suitable for evaluating the safety factors or probability of failure, while AutoCAD was used to draw the model following full dimensions and the dike's incline angles.

\subsection{Development}

\subsubsection{Phase 1}

Firstly, the dam construction is simulated, presented by Pirete (2013), and then, as shown in Figure 11, the model is drawn in AutoCAD 2019 with all its Geotechnical characteristics, followed by a different color for each type of material. After the initial drawing, the image was exported to Slide 2018, whereby each type of material (Table 2) is assigned, and then the water table was added along with the constant distribution load of $50 \mathrm{kPa}$ at the crest of the dam simulating the pond (Figure 12). 
For reference, the Bishop Simplified method was used in all four cases.

Table 2 - Geotechnical parameters of the Dam I (Pirete and Gomes, 2013)

\begin{tabular}{|l|c|c|c|}
\hline Material & $\mathrm{y}\left(\mathrm{kN} / \mathrm{m}^{3}\right)$ & $\mathrm{C}(\mathrm{kPa})$ & $\emptyset\left(^{\circ}\right)$ \\
\hline Residual soil (foundation) & 20 & 20 & 30 \\
\hline Starter dam (compacted soil) & 20 & 5 & 36 \\
\hline Compacted soil & 20 & 10 & 30 \\
\hline Compacted tailings & 25 & 5 & 40 \\
\hline Dilative tailings & 22 & 20 & 38 \\
\hline
\end{tabular}




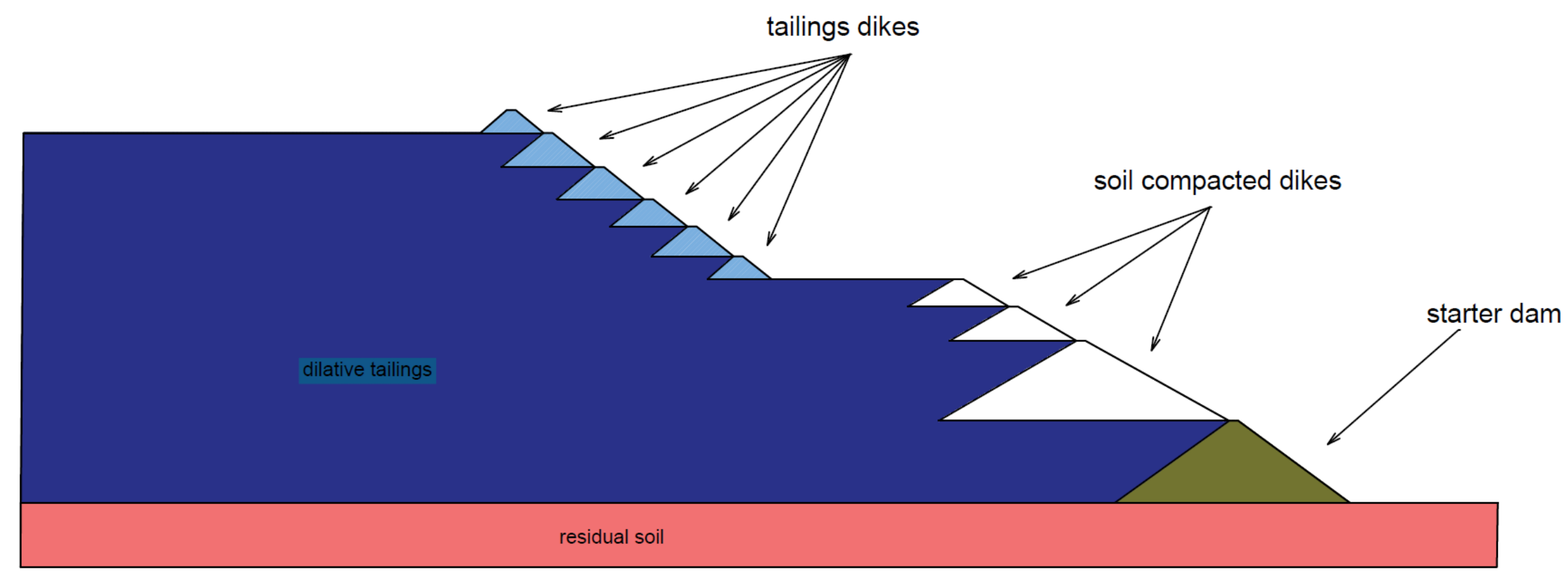

Figure 11 - Tailings Dam I profile 


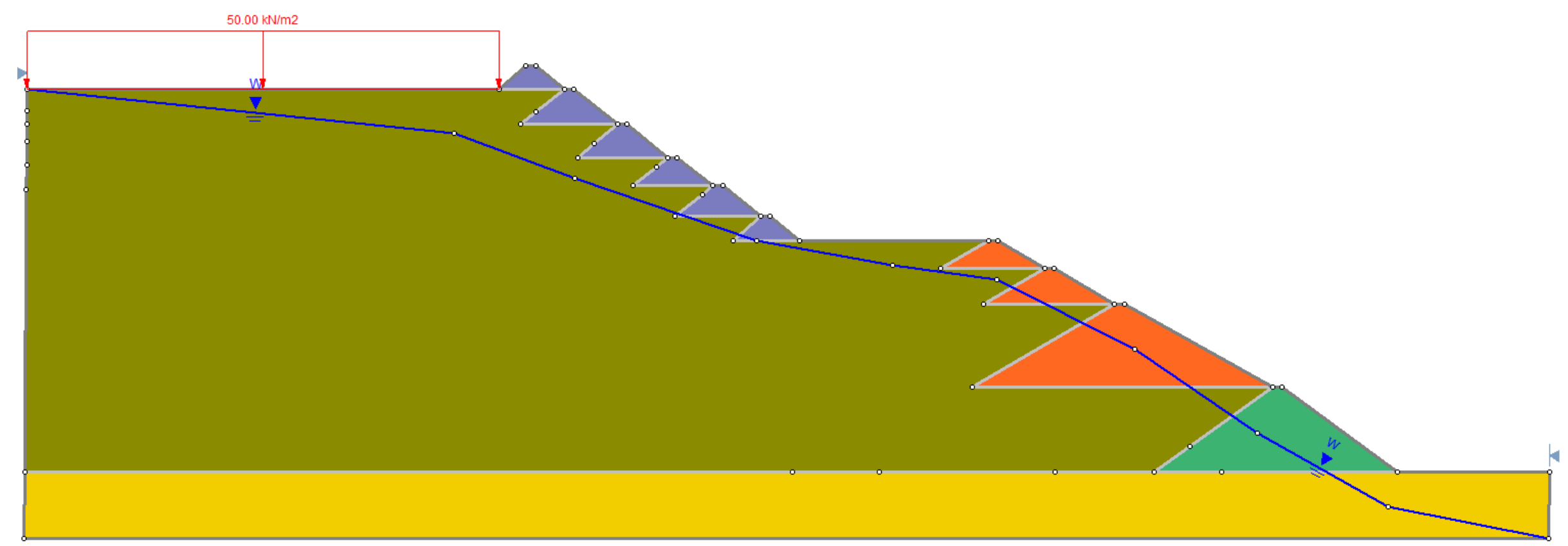

Figure 12 - Layout of the Dam I in Slide 2018 


\subsubsection{Phase 2}

After the initial drawing and assigning material properties to each part of the dam, the next phase was initiated. In Phase 2, the main priority was to define the number and properties for each scenario.

In Scenario I, the focus is on simulating the static of the dam without applying any of the outside distractions, which is a common situation during most times of the year. Scenario II is developed with the application of horizontal seismic stress. In Scenario III, the target is to calculate the intensity of the horizontal seismic coefficient that leads to the safety factor of 1 . Lastly, Scenario IV represents the situation when the drought is at its peak. In this scenario, the pond is eliminated from the crest of the tailings dam and the water table as well, without changing any Geotechnical parameters of the materials of the dam. More about each scenario will be discussed later.

\subsubsection{Phase 3}

For a deeper understanding of the safety factor transition from lower to higher failure probability (or vice versa), a multiple regression analysis was conducted. In this report, different parameters were taken into consideration of the cohesion and friction angle because, during some research, it is concluded that the cohesion and friction angle are parameters that can easily change. Parameters are not changed for every part of the dam but only for critical ones, such as the first five dikes (out of 10) and tailings deposition. Our parametric study was completed by changing one parameter at a time (either cohesion or friction angle) up or down by 1,2,3, or 7 while keeping everything else constant (default parameters). Therefore, 32 observations were done for each scenario, which gives us a total of 128 models. 


\section{Chapter 3}

\section{Results}

\subsection{Scenario I - Safety Factor Calculation}

After the material characteristics were input and assigned to each part of the dam, the safety factor was calculated. On the crest of the dam, the water pressure of $50 \mathrm{kN}$ per square meter was simulated, and that represented the pond, which is common in rainfall regions. The result showed that the most critical part of the slope is the toe (starter dam) and the next three dikes. The safety factor for that part of the slope was only 1.305 (Figure 13).

Proposed flow failure potential range is:

- $\quad$ FS $>1.5: \rightarrow$ Unlikely.

- $\quad 1.3 \leq \mathrm{FS} \geq 1.5: \rightarrow$ Low.

- $\quad 1.1 \leq \mathrm{FS} \geq 1.3: \rightarrow$ Moderate.

- FS $<1.1: \rightarrow$ High.

Therefore, the resulting safety factor of 1.305 goes to "Low" flow failure potential, which is very serious because the upstream tailing methods are very sensitive. Additional inspections, repair, and support should be done. 


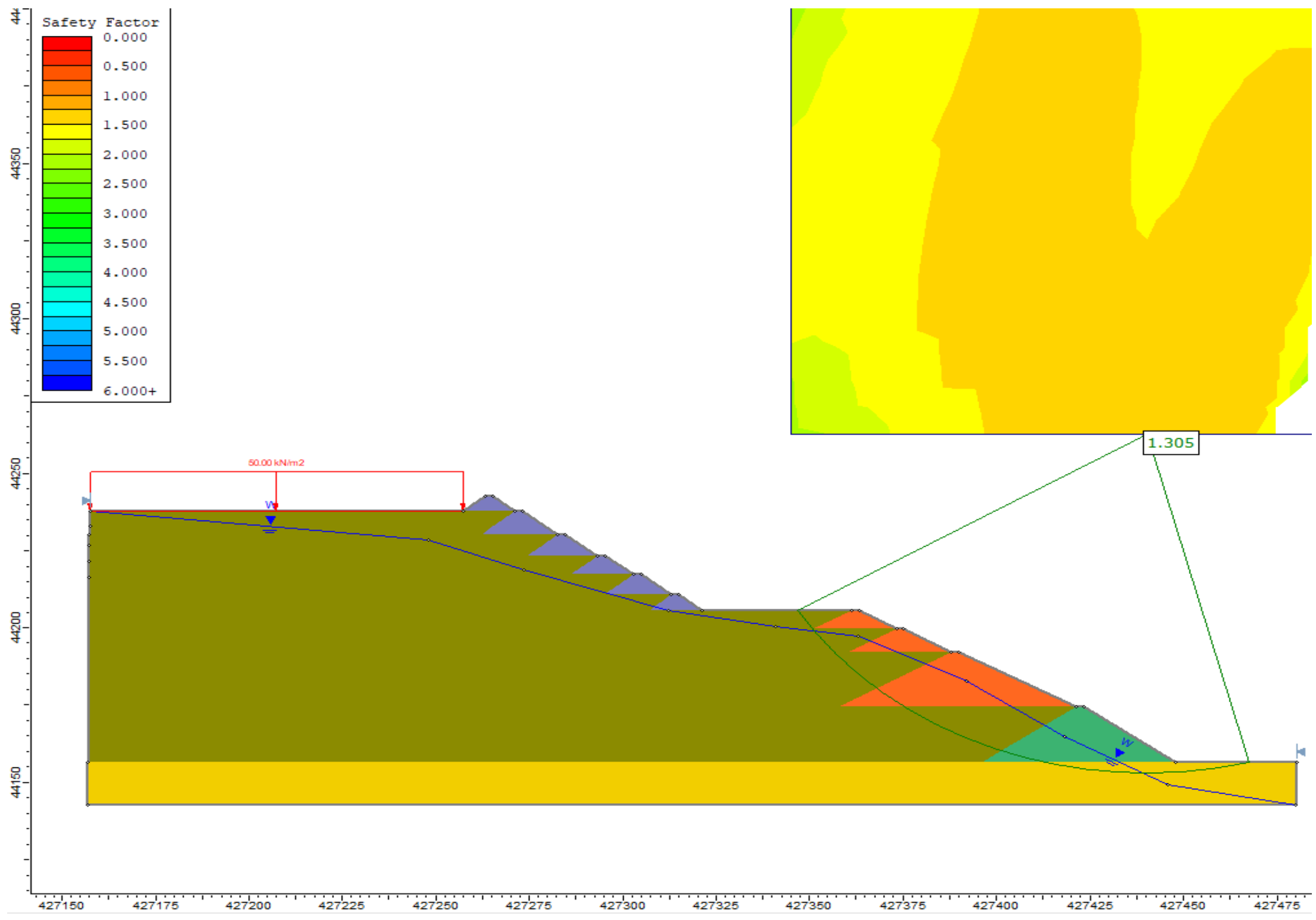

Figure 13 - Slope stability under the water pressure 
Parametric analysis for Scenario I

After performing a regression analysis, it is concluded that not all parameters are significant predictors of a safety factor but that some of them are. In the first scenario, coefficients are provided in the table below (Table 3).

Table 3 -Regression analysis coefficients of significant predictors for the first scenario

\begin{tabular}{|l|l|}
\hline & Coefficients \\
\hline Intercept & 0.041095647 \\
\hline Starter Dam (Cohesion) - SD & 0.001983246 \\
\hline Starter Dam (Friction angle) - SD & 0.015944444 \\
\hline Dilative Tailings (Cohesion) - DT & 0.00021595 \\
\hline Dilative Tailings (Friction angle) - DT & 0.017611111 \\
\hline
\end{tabular}

According to given coefficients, the safety factor for Scenario I can be predicted by using Equation 3:

$F S=0.041095647+S D_{C} * 0.001983246+S D_{F} * 0.015944444+D T_{C} * 0.00021595+$ $D T_{F} * 0.17611111$ 


\subsection{Scenario II - Seismic Activity Simulation}

In the second scenario, the horizontal seismic activity showing positive in the direction of failure was simulated. A seismic load coefficient of 0.15 was used, which represents the regular measure for the US region (coefficient goes from 0.05 to 0.15 ), therefore the least favorable situation (the biggest coefficient) needed to be considered (Table 5).

Analyzing this situation, the conclusion was that the safety of the dam is jeopardized because the factor of safety is 0.935 (Figure 14).

If an earthquake or any other major seismic activity occurred, the slope would fail because the safety factor is below 1 . 


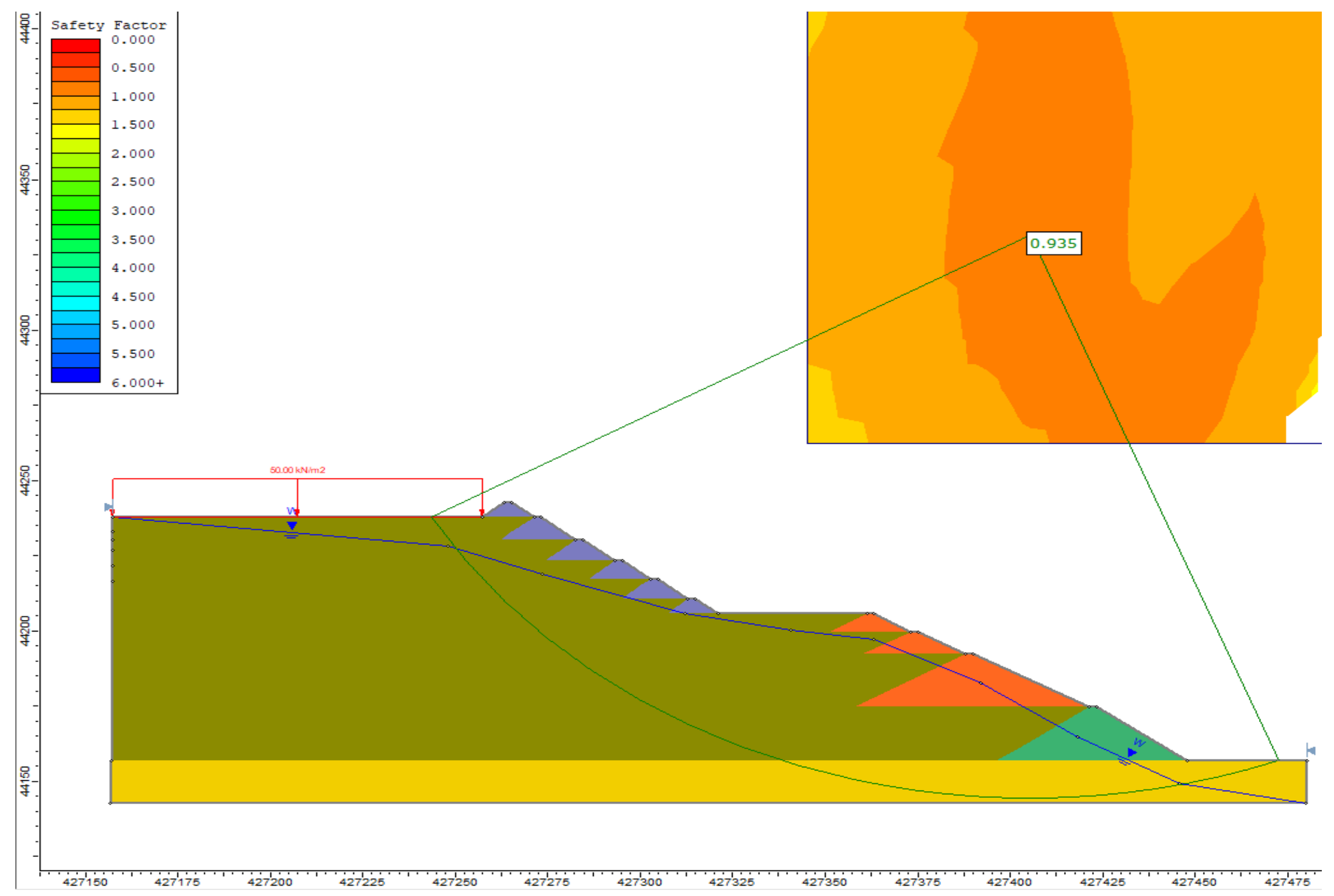

Figure 14-Critical part under the seismic activity 
Parametric analysis for Scenario II

After performing a regression analysis, it is concluded that not all parameters are significant predictors of the safety factor. In the second scenario, the coefficients are provided in the table below (Table 4).

Table 4-Regression analysis coefficients of significant predictors for the second scenario

\begin{tabular}{|l|l|}
\hline & Coefficients \\
\hline Intercept & 0.190470803 \\
\hline Starter Dam (Cohesion) - SD & 0.00041831 \\
\hline Starter Dam (Friction angle) - SD & 0.007809524 \\
\hline Dilative Tailings (Cohesion) - DT & -0.000341046 \\
\hline Dilative Tailings (Friction angle) - DT & 0.012134921 \\
\hline
\end{tabular}

According to given coefficients, our safety factor for Scenario II can be predicted by using Equation 4:

$F S=0.190470803+S D_{C} * 0.00041831+S D_{F} * 0.007809524-D T_{C} * 0.000341046+$ $D T_{F} * 0.012134921$ 


\subsection{Scenario III - Critical Acceleration Simulation}

This method falls under the advanced seismic analysis by specifying a horizontal seismic coefficient. The factor of safety that is targeted in this situation is 1 . By computing the analysis, the result shows a horizontal seismic coefficient that is equal to 0.199 (Figure 15). It can be identified as a critical coefficient because when it is reached, the factor of safety is 1 and the dam stability is endangered.

Table 5 - Horizontal seismic coefficient (Melo and Sharma, 2004)

\begin{tabular}{|c|c|c|}
\hline $\begin{array}{l}\text { Horizontal Seismic } \\
\text { Coefficient, } \mathrm{k}_{\mathrm{h}}\end{array}$ & \multicolumn{2}{|c|}{ Description } \\
\hline $0.05-0.15$ & \multicolumn{2}{|l|}{ In the United States } \\
\hline $0.12-0.25$ & \multicolumn{2}{|l|}{ In Japan } \\
\hline 0.1 & "severe" earthquakes & \multirow{3}{*}{ Terzaghi [4] } \\
\hline 0.2 & "violent, destructive" earthquakes & \\
\hline 0.5 & "catastrophic" earthquakes & \\
\hline $0.1-0.2$ & \multicolumn{2}{|l|}{ Seed [2], POS $\geq 1.15$} \\
\hline 0.10 & Major Earthquake, FOS > 1.0 & \multirow{2}{*}{ Corps of Engineers [5] } \\
\hline 0.15 & Great Earthquake, FOS > 1.0 & \\
\hline $1 / 2$ to $1 / 3$ of $\mathrm{PHA}$ & \multicolumn{2}{|l|}{ Marcuson [6], FOS > 1.0} \\
\hline $1 / 2$ of PHA & \multicolumn{2}{|l|}{ Hynes-Grifin [7], FOS > 1.0} \\
\hline \multicolumn{3}{|c|}{ FOS = Factor of Safety. PHA = Peak Horizontal Acceleration, in g's } \\
\hline
\end{tabular}




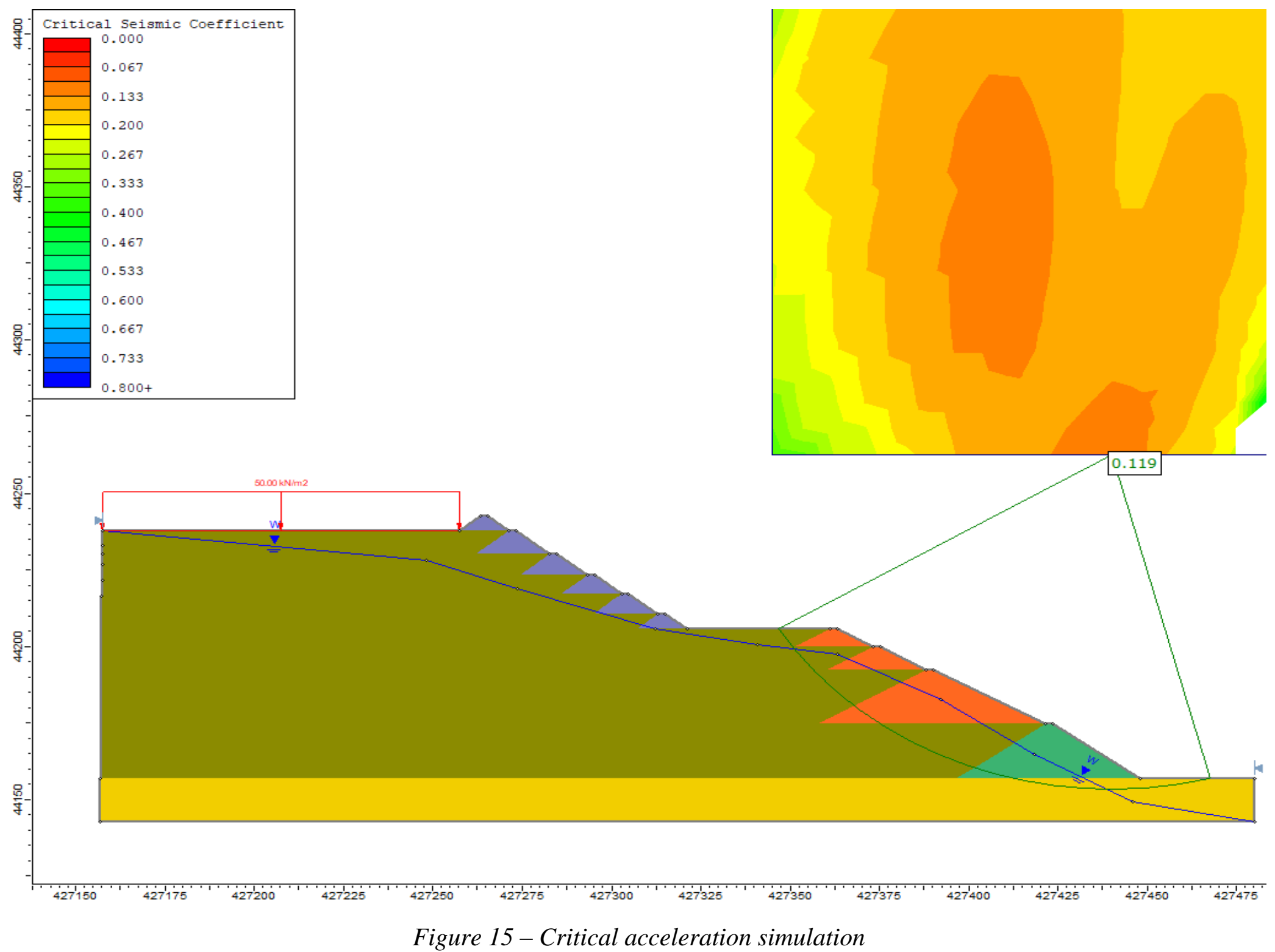


Parametric analysis for Scenario III

After performing a regression analysis, it is concluded that not all parameters are significant predictors of the safety factor. In the third scenario, the coefficients are provided in the table below (Table 6).

Table 6-Regression analysis coefficients of significant predictors for the third scenario

\begin{tabular}{|c|c|}
\hline & Coefficients \\
\hline Intercept & -0.281834749 \\
\hline Starter Dam (Cohesion) - SD & 0.000629036 \\
\hline Starter Dam (Friction angle) - SD $_{\mathrm{F}}$ & 0.004801587 \\
\hline Dilative Tailings (Cohesion) - DT & $-9.70438 \mathrm{E}-05$ \\
\hline Dilative Tailings (Friction angle) - DT & 0.005873016 \\
\hline
\end{tabular}

According to given coefficients, the horizontal seismic coefficient for Scenario III is predicted by using Equation 5:

$H S C=-0.281834749+S D_{C} * 0.000629036+S D_{F} * 0.004801587-D T_{C} *$ $9.70438 E^{-05}+D T_{F} * 0.005873016$ 


\subsection{Scenario IV - Perfect Drainage (No water pressure)}

To try to simulate as many as possible scenarios and analyze dam stability, in the last scenario, the water table was eliminated, as well as the water pressure from the crest of the dam. This simulation represents the perfect drainage system whereby rain and groundwater do not cause any pressure on the dam and tailings. This scenario is unlikely possible but could happen.

As a result of this simulation method, the factor of safety is 1.449 (Figure 16), which is satisfying, and the dam is safe when the dam is completely dry. 


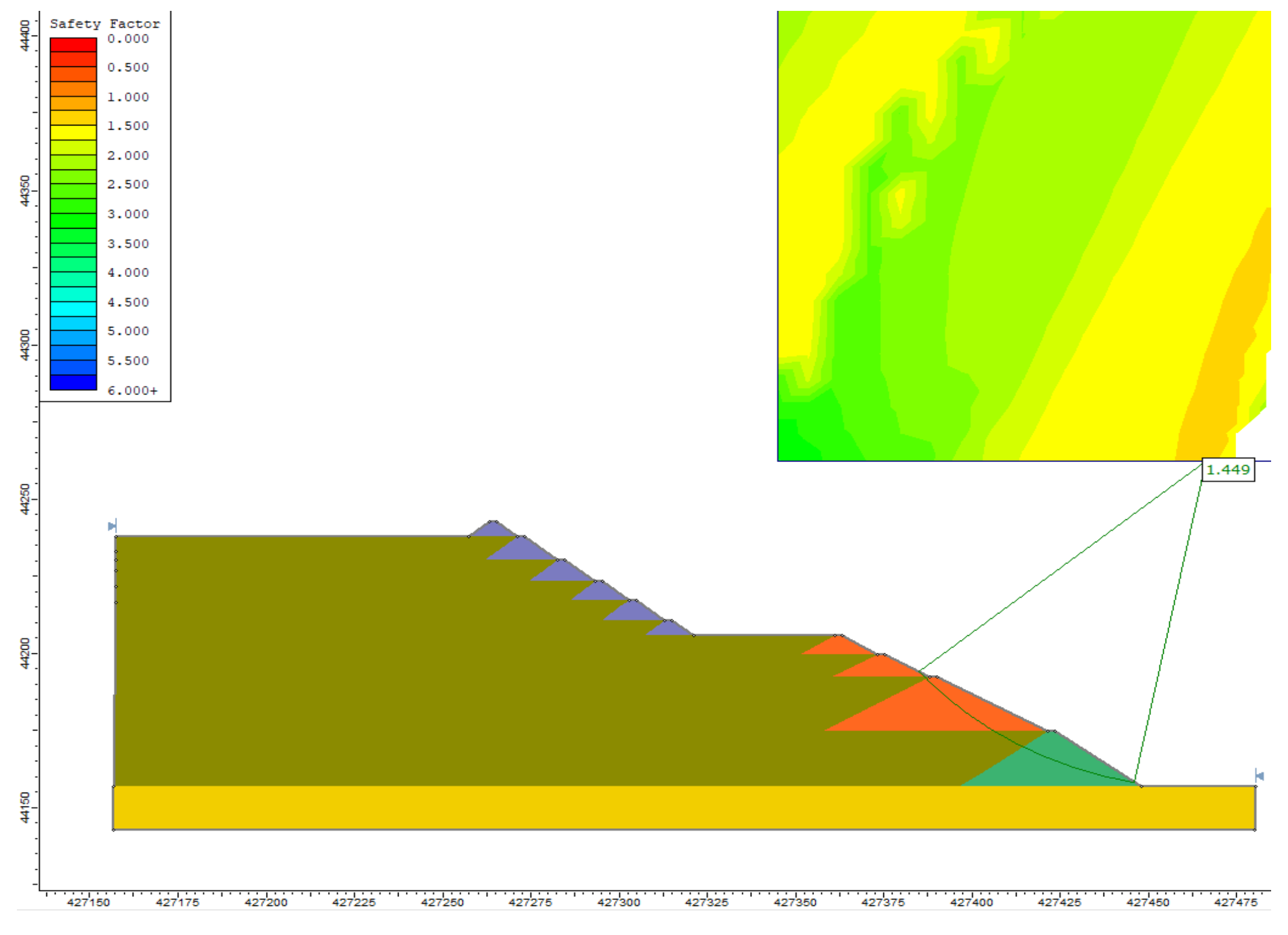

Figure 16-Completely dry tailings dam 
Parametric analysis for Scenario IV

After performing a regression analysis, it is concluded that not all parameters are significant predictors of safety factor but that some of them are. For the fourth scenario, coefficients are provided in the table below (Table 7).

Table 7 - Regression analysis coefficients of significant predictors for the fourth scenario

\begin{tabular}{|l|l|}
\hline & Coefficients \\
\hline Intercept & 0.038962569 \\
\hline Starter Dam (Cohesion) - SD & 0.014907507 \\
\hline Starter Dam (Friction angle) - SD & 0.027492063 \\
\hline Dilative Tailings (Cohesion) - DT & 0.000216839 \\
\hline Dilative Tailings (Friction angle) - DT & 0.008849206 \\
\hline
\end{tabular}

According to the given coefficient, the safety factor for the Scenario IV can be predicted by using Equation 6:

$F S=0.038962569+S D_{C} * 0.014907507+S D_{F} * 0.027492063-D T_{C} * 0.000216839+$ $D T_{F} * 0.008849206$ 


\section{Chapter 4}

\section{Conclusion}

It is hard to ascertain any single factor that triggered the collapse of Dam I. There were a handful of reasons why the failure occurred.

According to given scenarios, it is obvious that the tailings dam had some deficiencies. The lack of proper construction, management, maintenance, internal drainage, high iron content, seepage, and so on, caused the failure.

Some articles have stated that workers alerted management about the problems with the dam, but for some reason, the company's representatives stayed silent.

We hope a disaster like this will never happen again.

\subsection{Environmental Impact}

Toxic mud flowed for five miles, destroying homes, and offices, and killing people. The Brazilians had not seen a catastrophe like this before.

The slurry traveled downhill to the Rio Paraopeba River, killing most of the animals and contaminating the drinking water along the river. 


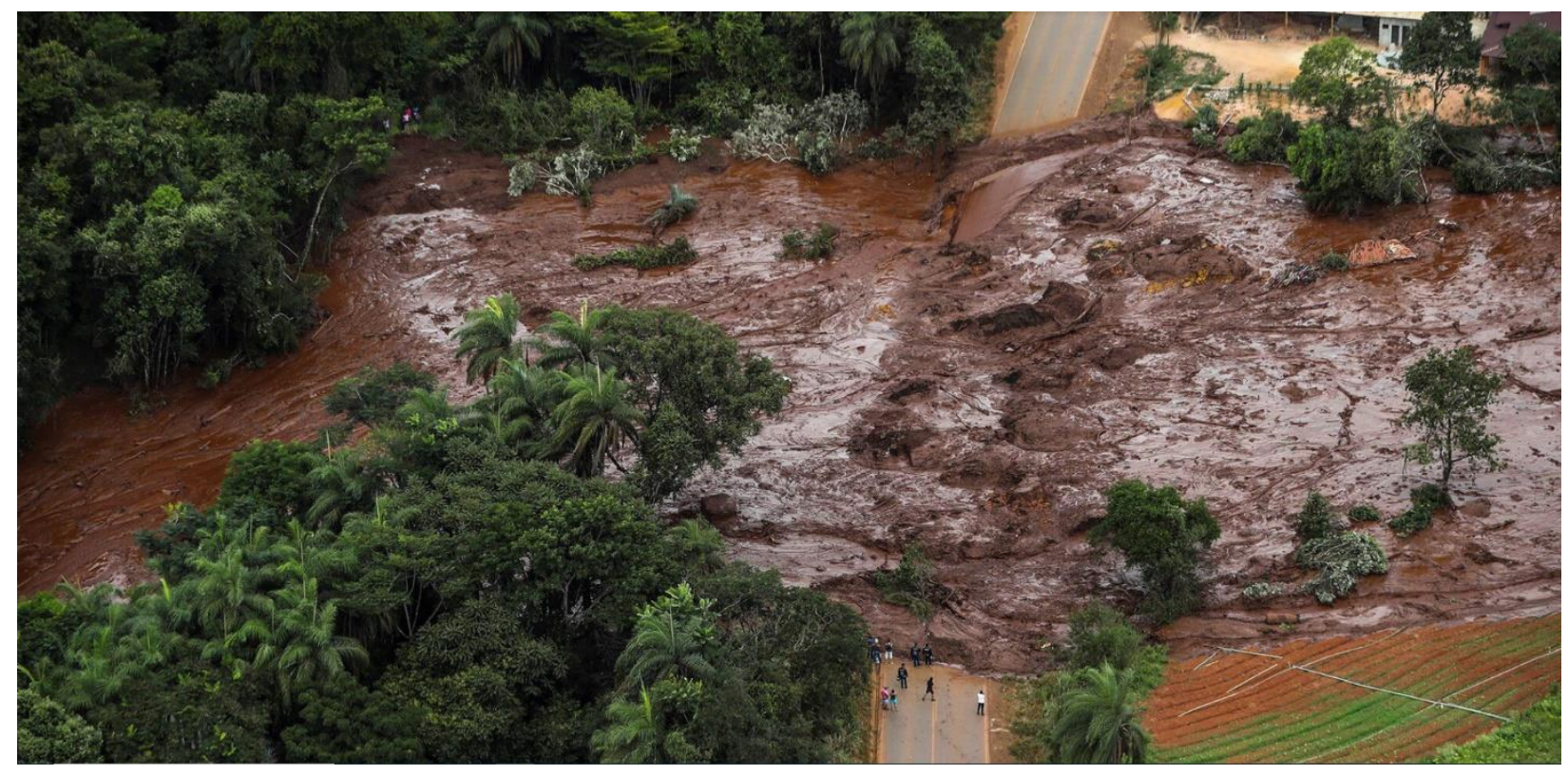

Figure 17 - Tailing's mudflow (Darlington et al., 2019)

The historical record of the tailings from 2006 showed a high concentration of iron (more than $50 \%$ ) and a low concentration of silica (less than 10\%). Corresponding to that, high toxicity left a significant footprint on the river and the surrounding soil, as shown in Figure 17. It impacted the nearby crops and drinking water, and it will take decades for nature to recover itself. The point of environmental protection is not to calculate the costs when an incident occurs, it is about taking steps to prevent a recurring catastrophe. Reparations to a plant after the incident occurred is shown in Figure 18. 


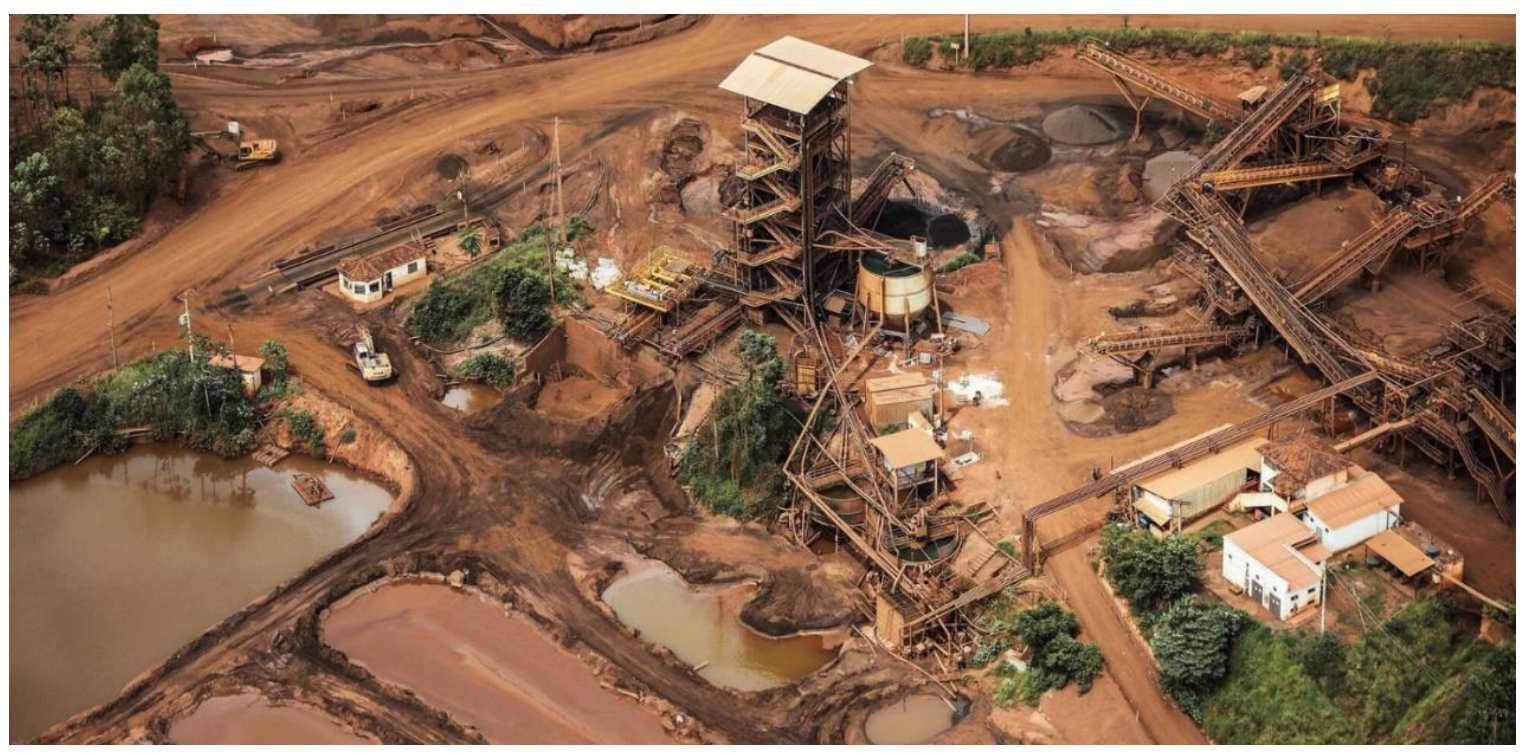

Figure 18 - Reparations to a plant after the incident (Darlington et al., 2019)

\subsection{Economic Impact}

Instead of investing probably a couple of thousand dollars in mitigating the slope, the company, Vale S.A., the owners of the mine, eventually faced expenses of billions of dollars in lawsuits and reimbursements. The total cost of the disaster has not been calculated yet, but surely it can be said that it will significantly impact Vale's business and the entire iron ore market. Vale vowed 27,000 US dollars to families for each life lost in the disaster. But it must be noted that not only direct costs play a role, but there are also indirect costs too. The company's public image has been seriously jeopardized.

Figure 19 shows the iron ore stock market price in the last couple of years.

On a single day, when the disaster occurred, Vale S.A. stock price fell by $24 \%$, losing US\$19 billion in market capitalization. 


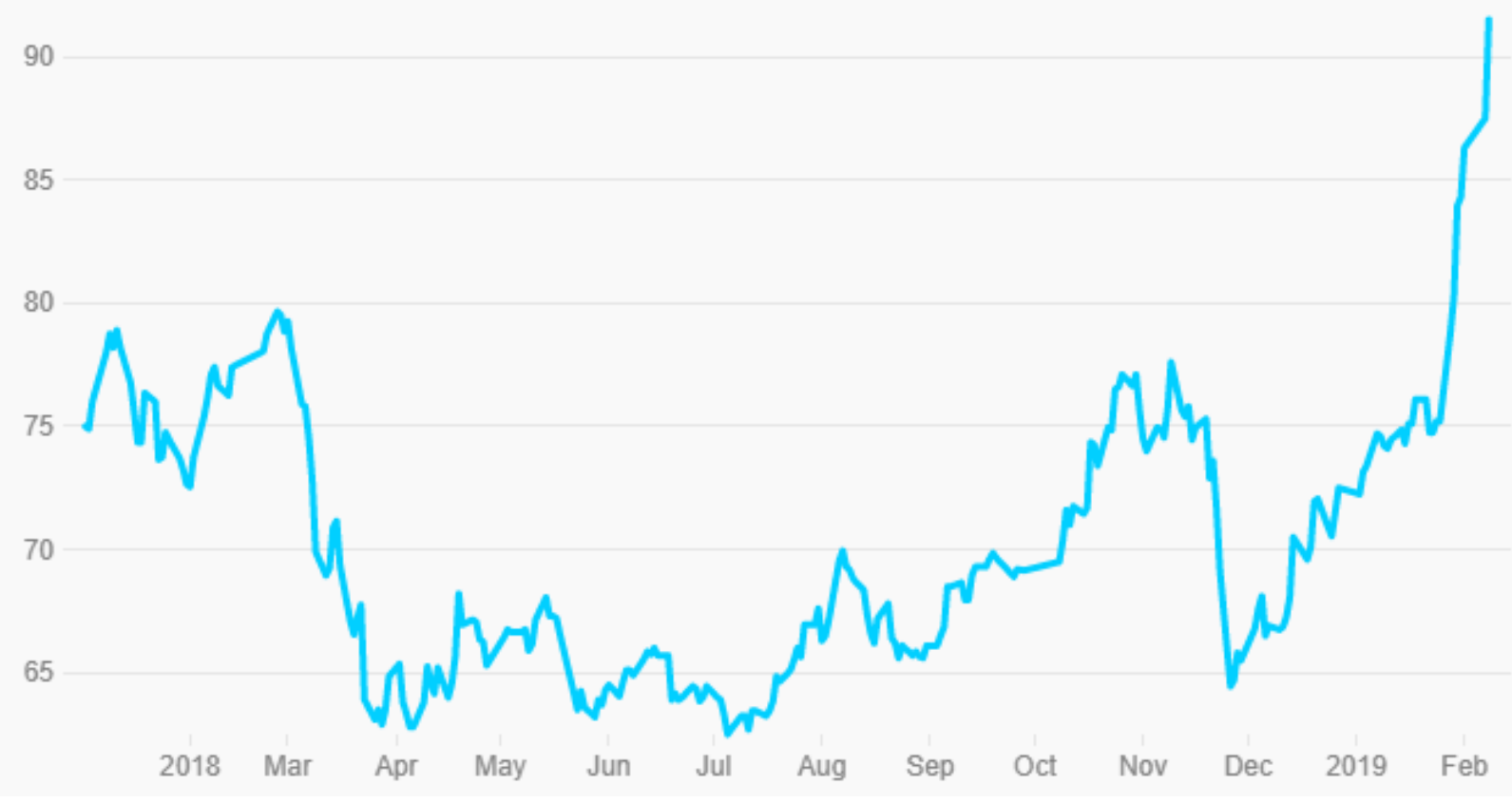

Figure 19 - Iron ore stock market (Diss, 2019)

After the catastrophe, all deficiencies related to upstream tailings dam construction came to the surface and the Brazilian government ordered the closure, repair, or inspection of every tailings dam that had a moderate or likely chance of failure.

\subsection{Social Impact}

Most of the community around the mine looked at the company as the only source of income. Many family members worked at the mine to keep the bread on the table. After the catastrophe, society is still divided. Half of them are still very disappointed and angry with the company management because they did not take the workers' alert seriously. The other half said that they would still work there because they did not have any other source of income.

Vale betrayed the Brumadinho community. The salaries of mineworkers in Brazil are not worth being exposed to a catastrophe. 
Even though the company promised that every dam would be inspected, and recommendations seriously considered after the disaster with the Mariana Dam in November 2015, they have failed to do that. 


\section{References}

1. Blight, G. E., Fourie, A. B., 2005, “Catastrophe Revisited - Disastrous Flow Failures of Mines and Municipal Solid Waste," Geotechnical and Geological Engineering, Vol. 23, Issue No. 3, 3 pp.

2. Bryne, P. M., 1991, "A Model for Predicting Liquefaction Induced Displacement," Second International Conference on Recent Advances In Geotechnical Earthquake Engineering and Soil Dynamics, March 11-15, 1991, St. Louis, Missouri, Paper No. 7.14.

3. Chaulya, S. K., Prasad, G. M., 2016, "Slope Failure Mechanism and Monitoring Techniques" < https://www.sciencedirect.com/topics/engineering/shear-strength>

4. Darlington, S., Glanz, J., Andreoni, M., Bloch, M., Pecenha, S., Singhvi, A., Griggs, T., 2019, “Brumadinho Dam Collapse: A Tidal Wave of Mud,” NY Times, April 2020, $<\underline{\text { https://www.nytimes.com/interactive/2019/02/09/world/americas/brazil-dam- }}$ $\underline{\text { collapse.html > }}$

5. Diss, K., “Brazil’s Brumadinho Mining Disaster Will Hurt Vale, but Iron Ore Firms and Australia's Economy are Set to Cash In, ” ABC Net, February 2019, $<$ https://www.abc.net.au/news/2019-02-12/iron-ore-price-explainer-after-mining-dam$\underline{\text { collapse/10800698> }}$

6. Guardian News. (2019, February 1). Terrifying moment of Brazil dam collapse caught on camera [Video file]. Retrieved from https://www.youtube.com/watch?v=sKZUZQytads

7. Jeyapalan, J. K., Duncan, J. M., Seed. B. H., 1984 “Analysis of Flow Failures of Mine Tailings Dams,” Journal of Geotechnical Engineering, Vol. 110, Issue No. 3, 3 pp.

8. Jeyapalan, K., 1980, “Analyses of Flow Failures of Mine Tailings Impoundments,” Ph.D. Thesis, University of California, Berkley, CA., 3 pp.

9. Lottermoser, B. G., 2010, Mine Wastes, $3^{\text {rd }}$ Edition, 2 pp. 
10. Lyu, Z., Chai, J., Xu, Z., Qin, Y., Cao, J., 2019, “A Comprehensive Review on Reasons for Tailings Dam Failures Based on Case History," Advances in Civil Engineering, Vol. 2019, 2 pp.

11. Martin, T.E., 1999, “Characterization of Pore Pressure Conditions in Upstream Tailings Dams," Proc. Tailings and Mine Waste, Fort Collins, Colorado, 5 pp.

12. McLeod, H., and A. Bjelkevik. 2017. “Tailings Dam Design: Technology Update (ICOLD Bulletin),, in Proceedings of the 85th Annual Meeting of International Commission on Large Dams, July 3-7, 2017. Prague, Czech Republic: Czech National Committee on Large Dams.

13. Melo, C., Sharma, S., "Seismic Coefficients for Pseudostatic Slope Analysis," $13^{\text {th }}$ World Conference on Earthquake Engineering, August 1-6, 2004, Vancouver, B.C., Canada.

14. Michael, P., Murguia, R., Koraseo, L., 2005 “The Flowability of Impounded Coal Refuse," US Department of the Interior, Office of Surface Mining, August, 5 pp.

15. Mittal, H. K., 1974, "Design and Performance of Tailings Dams," Ph.D. Thesis, University of Alberta, Edmonton, Alberta, 5 pp.

16. Pacheco, R. L. R., 2919, "Static Liquefaction in Tailings Dam and Flow Failure," Instituto Geologico y Minero de Espana, Madrid, Spain, 5 pp.

17. Pirete, W., Gomes, R.C., 2013, “Tailings Liquefaction Analysis Using Strength Ratios and SPT/CPT Results," An International Journal of Geotechnical and Geoenvironmental Engineering, Vol. 36, No. 1, pp. 37-54.

18. Priscu, C., 1999, “Behavior of Mine Tailings Dams Under High Tailings Deposition Rates," Ph.D. Thesis, McGill University, Montreal, 10 pp. 
19. Robertson, P. K., Melo, L. D., Williams, D. J., Wilson, G. W. 2019. "Report of the Expert Panel on The Technical Causes of the Failure of Feijao Dam I,’ December, 10 pp.

20. Simms, P., 2016, “2013 Colloquium of the Canadian Geotechnical Society: Geotechnical and Geoenvironmental Behaviour of High-Density Tailings," Canadian Geotechnical Journal, Vol. 54, No. 4, 5 pp.

21. “The Brumadinho Tailings Dam Failure (Minas Gerais, Brazil),” WISE Uranium Project, February 2020, <https://www.wise-uranium.org/mdafbr.html > Skopek, P., 1994, “Collapse Behavior of Very Loose, Dry Sand,” Ph.D. Thesis, University of Alberta, Edmonton, Alberta, 3 pp.

22. United States Environmental Protection Agency, 1994, Design and Evaluation of Tailings Dams, 20 pp.

23. Vallejo, L. E., Scovazzo, V. A., 2003, "Determination of the Shear Strength Parameters Associated with Mudflows," Soils and Foundations, Vol. 43, No. 2, 2 pp.

24. Wickland, B. E., Wilson, W. G., Wijewickreme, D., Klein, B., 2005, “Design and Evaluation of Mixtures of Mine Waste Rock and Tailings," Geotechnical and Geological Engineering, Vol. 23, Issue No. 3, 4 pp.

25. Wickland, B. E., Wilson, W. G., Wijewickreme, D., 2010, "Hydraulic Conductivity and Consolidation Response of Mixture of Mine Waste Rock and Tailings," Canadian Geotechnical Journal, Vol. 47, No. 4, 5 pp.

26. Yond, T. L., Power, M., Greene., Bertero, V., Frohmberg, K., Gath, E., Hays, W., 1994, "Liquefaction: What it is and what to do about it," Earthquake Engineering Research Institute, Oakland, CA, 5 pp. 